\title{
Efficacy of mitigation measures for reducing greenhouse gas emissions from intensively cultivated peatlands
}

Taft, Helen; Cross, Paul; Jones, Davey L.

\section{Soil Biology and Biochemistry}

DOI:

10.1016/j.soilbio.2018.08.020

Published: 01/12/2018

Peer reviewed version

Cyswllt i'r cyhoeddiad / Link to publication

Dyfyniad o'r fersiwn a gyhoeddwyd / Citation for published version (APA):

Taft, H., Cross, P., \& Jones, D. L. (2018). Efficacy of mitigation measures for reducing greenhouse gas emissions from intensively cultivated peatlands. Soil Biology and Biochemistry, 127, 10-21. https://doi.org/10.1016/j.soilbio.2018.08.020

\footnotetext{
Hawliau Cyffredinol / General rights

Copyright and moral rights for the publications made accessible in the public portal are retained by the authors and/or other copyright owners and it is a condition of accessing publications that users recognise and abide by the legal requirements associated with these rights.

- Users may download and print one copy of any publication from the public portal for the purpose of private study or research.

- You may not further distribute the material or use it for any profit-making activity or commercial gain

- You may freely distribute the URL identifying the publication in the public portal ?
}

Take down policy

If you believe that this document breaches copyright please contact us providing details, and we will remove access to the work immediately and investigate your claim. 


\section{Accepted Manuscript}

Efficacy of mitigation measures for reducing greenhouse gas emissions from intensively cultivated peatlands

Helen E. Taft, Paul A. Cross, Davey L. Jones

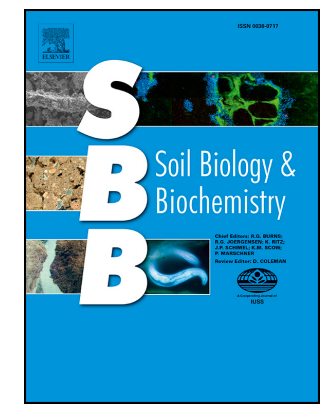

PII:

S0038-0717(18)30274-8

DOI:

10.1016/j.soilbio.2018.08.020

Reference: SBB 7258

To appear in: Soil Biology and Biochemistry

Received Date: 14 March 2018

Revised Date: 15 August 2018

Accepted Date: 17 August 2018

Please cite this article as: Taft, H.E., Cross, P.A., Jones, D.L., Efficacy of mitigation measures for reducing greenhouse gas emissions from intensively cultivated peatlands, Soil Biology and Biochemistry (2018), doi: 10.1016/j.soilbio.2018.08.020.

This is a PDF file of an unedited manuscript that has been accepted for publication. As a service to our customers we are providing this early version of the manuscript. The manuscript will undergo copyediting, typesetting, and review of the resulting proof before it is published in its final form. Please note that during the production process errors may be discovered which could affect the content, and all legal disclaimers that apply to the journal pertain. 
1 Efficacy of mitigation measures for reducing greenhouse gas emissions from intensively

2 cultivated peatlands

3

4 Helen E. Taft ${ }^{*}$, Paul A. Cross, Davey L. Jones

5 School of Environment, Natural Resources and Geography, Bangor University, Deiniol

6 Road, Bangor, Gwynedd, LL57 2UW, UK

7

$8 \quad$ * Corresponding author.

$9 \quad$ Email address: $\underline{\text { h.taft @ bangor.ac.uk }}$ 
10 ABSTRACT

11 Drained and cultivated fen peats represent some of the world's most productive soils, however, they are susceptible to degradation and typically exhibit high rates of greenhouse gas (GHG) emission. We hypothesised that GHG losses from these soils could be reduced by manipulating water table depth, tillage regime, crop residue application or horticultural fleece cover. Using intact soil columns from a horticultural peatland, emissions of $\mathrm{CO}_{2}, \mathrm{~N}_{2} \mathrm{O}$ and $\mathrm{CH}_{4}$ were monitored over a six-month period, using a closed-chamber method. Concurrent measurements of soil properties allowed identification of the key controls on GHG emissions. Raising the water table to the soil surface provided the strongest reduction in global warming potential $\left(G W P_{100} ; 26 \pm 6 \mathrm{~kg} \mathrm{CO}_{2}-\mathrm{e} \mathrm{ha}^{-1} \mathrm{~d}^{-1}\right)$, compared to a free-draining control $(81 \pm 1 \mathrm{~kg}$ $\mathrm{CO}_{2}-\mathrm{e} \mathrm{ha}^{-1} \mathrm{~d}^{-1}$ ), but this effect was partially negated by an emission pulse when the water table was subsequently lowered. The highest emissions occurred when the water table was maintained $15 \mathrm{~cm}$ below the surface $\left(172 \pm 12 \mathrm{~kg} \mathrm{CO}_{2}-\mathrm{e} \mathrm{ha}^{-1} \mathrm{~d}^{-1}\right)$, as this stimulated $\mathrm{N}_{2} \mathrm{O}$ loss. Placement of horticultural fleece over the soil surface during spring had no significant effect on $G W P_{100}$, but prolonged fleece application exacerbated GHG emissions. Leaving lettuce crop residues on the surface increased soil GWP $100\left(106 \pm 4 \mathrm{~kg} \mathrm{CO}_{2}-\mathrm{e} \mathrm{ha}{ }^{-1} \mathrm{~d}^{-1}\right)$ in comparison to when residues were incorporated into the soil $\left(85 \pm 4 \mathrm{~kg} \mathrm{CO}_{2}-\mathrm{e} \mathrm{ha}^{-1} \mathrm{~d}^{-1}\right)$, however, there was no evidence that this promoted positive priming of native soil organic matter (SOM). For maximum abatement potential, mitigation measures should be applied during the growing season, when GHG emissions are greatest. Our results also suggest that introduction of zeroor minimum-till practices may not reduce GHG emissions. Maintaining a high water table was the only option that reliably reduced GHG emissions, however, this option is impractical to implement within current horticultural systems. We conclude that alternative strategies or a major change in land use (e.g., conversion from horticulture/arable to wetland) should be explored as a means of preserving these soils for future generations. 
Keywords: Carbon cycling; Food security; Greenhouse gases; Histosol; Sustainable cropping

\section{Introduction}

Approximately $14-20 \%$ of peatlands globally are used for agriculture and when

drained and cultivated they represent some of the world's most productive agricultural soils

(IPS, 2008). Their management is highly problematic, however, due to the potential for soil

loss, either from wind or water erosion or from microbial mineralisation of the peat substrate

(Dawson and Smith, 2007). Whilst microbial activity results in the release of nutrients

previously locked up in soil organic matter (SOM), thereby enhancing crop productivity, it

also progressively diminishes the resource base (Cannell et al., 1999). There is therefore a

clear ecosystem services trade-off between (1) preserving (and enhancing) peat carbon (C)

storage for climate change mitigation, maintaining high biodiversity habitats, and improving water quality, and (2) using this resource to promote food security.

national emissions of greenhouse gas (GHGs) from peat sources (IPS, 2008). For example, it has been estimated that $39 \%$ of English deep fen peats are currently under intensive cultivation and classed as being at risk from severe soil loss (Natural England, 2010). Within these sites, the depth of soil has been declining by $0.27-3.09 \mathrm{~cm} \mathrm{y}^{-1}$ since the onset of drainage and cultivation in 1850 (Richardson and Smith, 1977; Hutchinson, 1980; Dawson et al., 2010). It has been estimated that $35-100 \%$ of drained Histosol loss may be attributable to microbially mediated $\mathrm{CO}_{2}$ production (Leifeld et al., 2011). The small net consumption of

$57 \mathrm{CH}_{4}$ in these soils does little to offset $\mathrm{CO}_{2}$ loss, whilst $\mathrm{N}_{2} \mathrm{O}$ emissions can be substantial, forming approximately one third to one half of the total GHG budget (Taft et al., 2017). 
60

substantially reduce the agricultural C footprint in some countries (UK Parliament, 2008;

Kløve et al., 2017).

Agricultural soil GHG emissions are influenced by a large number of interacting factors, including those associated with soil (e.g., porosity, labile C), climate (rainfall, temperature), and vegetation (growth rate, rooting depth), which in turn are driven by agricultural management strategy (Li, 2007). Modifying a single factor may simultaneously increase emissions of one GHG and result in the reduction of another (Smith et al., 2008).

Therefore, mitigation studies should consider the overall effect of a measure on the total emissions of $\mathrm{CO}_{2}, \mathrm{CH}_{4}$ and $\mathrm{N}_{2} \mathrm{O}$, rather than on a single $\mathrm{GHG}$, as in some previous studies (Dalal et al., 2008; Henault et al., 2012; Musarika et al., 2017). This is particularly important where measures to reduce $\mathrm{CO}_{2}$ emission increase the release of the more radiatively powerful $\mathrm{CH}_{4}$ and $\mathrm{N}_{2} \mathrm{O}$, causing a disproportionately large increase in the overall global warming potential (GWP) of the system. Given the relationship between GHG efflux and soil organic C (SOC) loss (Dawson and Smith, 2007), and the importance of SOC to long-term soil sustainability, it is also useful for mitigation studies to include an estimate of the effects of treatments on SOC retention.

While many reviews on GHG mitigation in arable systems exist, few contain interventions specific to cultivated peatlands (e.g., Jauhiainen et al., 2016). Further, much of the evidence remains inconclusive. Our aim was to evaluate whether common management practices (i.e. tillage, manipulating water table depth, crop protection with fleece, and crop residue management) promoted or repressed GHG emissions and whether these could be used to promote SOC retention in cultivated peatlands. We hypothesised that tillage would promote soil aeration and net GHG loss, while conversely, raising the water table would reduce aeration and reduce net GHG loss. In addition, we hypothesized that fleece cover would increase soil temperature and moisture retention thereby promoting GHG emissions, 
while addition of crop residues might reduce GHG emissions through negative priming of SOM.

\section{Methods and materials}

\subsection{Study sites}

Soils (Sapric Histosols; FAO, 2006) utilised in this study originate from a horticultural lowland peatland in East Anglia, UK (52 $\left.32^{\prime} \mathrm{N}, 0^{\circ} 29^{\prime} \mathrm{E}\right)$. The site has a mean annual rainfall of $<700 \mathrm{~mm}$, a mean annual temperature of $10.2^{\circ} \mathrm{C}$ (ranging from mean 4.2 ${ }^{\circ} \mathrm{C}$ in winter to $17.2^{\circ} \mathrm{C}$ in summer), and mean annual sunshine hours of 1550 (UK MetOffice, 2014). The study area comprises drained lowland fen typified by flat topography, which is under intensive commercial-scale horticultural and arable production, growing primarily vegetables (including lettuces [Lactuca sativa L.], potatoes [Solanum tuberosum L.], leeks [Allium porrum L.], onions [Allium cepa L.], red beet [Beta vulgaris L.], and celery [Apium graveolens L.]), sometimes in rotation with cereals (primarily wheat [Triticum aestivum L.]). Soil was collected from a representative field ( $70 \%$ SOM content; Taft et al., 2017), which had been under a typical rotation for the previous growing season. Table 1 shows the physical and chemical characteristics of the soils used in the experiments.

\subsection{Field sampling}

Intact soil cores were taken from a visually representative area $\left(10 \mathrm{~m}^{2}\right)$ of a field to minimise any microsite variability caused by soil heterogeneity. A PVC pipe $\left(d_{\text {internal }}=103\right.$ $\mathrm{mm} ; h=400 \mathrm{~mm}$ ) with a chamfered base was slowly driven into the soil to give a final core depth of $300 \mathrm{~mm}$ with c. $100 \mathrm{~mm}$ remaining at the top of the core to act as chamber headspace when GHG sampling. After excavation, the cores were transported $\left(10^{\circ} \mathrm{C}\right)$ to the experimental site at Bangor University $\left(53^{\circ} 13^{\prime} \mathrm{N}, 4^{\circ} 9^{\prime} \mathrm{W}\right)$, where they were laid out in a 
randomised design with four blocks to allow for monitoring of background emissions of $\mathrm{CO}_{2}$,

$\mathrm{CH}_{4}$ and $\mathrm{N}_{2} \mathrm{O}$ prior to experimentation (no significant differences among cores were apparent; data not presented).

\subsection{Preliminary soil and residue analysis}

Five additional cores were taken from the field and a number of chemical and physical analyses performed before commencement of the experiment; the same analyses were conducted at the end of the experiment on all cores (Table 1). The cores were split into three layers (0-10, 10-20 and 20-30 cm depth) and analyses were performed on each layer. A Rhizon ${ }^{\circledR}$ suction sampler was inserted to $10 \mathrm{~cm}$ depth and a soil water sample obtained then stored at c. $-20{ }^{\circ} \mathrm{C}$ to await analysis. Next, a soil sample was taken using a bulk density ring $\left(h_{\text {total }}=10 \mathrm{~cm}, V_{\text {total }}=200 \mathrm{~cm}^{3}\right)$ for calculation of soil gravimetric moisture content and bulk density after oven drying $\left(105{ }^{\circ} \mathrm{C}, 24 \mathrm{~h}\right)$. The remaining soil was homogenised and stored at $4^{\circ} \mathrm{C}$ prior to chemical analysis within $48 \mathrm{~h}$. Soil samples extracts were performed in triplicate for each soil layer for the determination of available $\mathrm{NO}_{3}{ }^{-}$and $\mathrm{NH}_{4}{ }^{+}(5 \mathrm{~g}$ soil in $25 \mathrm{ml} 0.5 \mathrm{M}$ $\mathrm{KCl}$ ), available $\mathrm{P}$ (5 g soil in $25 \mathrm{ml} 0.5 \mathrm{M}$ acetic acid), and available $\mathrm{K}$ (5 g soil in $25 \mathrm{ml} 1 \mathrm{M}$ $\mathrm{NH}_{4} \mathrm{Cl}$ ). Extracts were obtained by shaking (200 rev $\left.\min ^{-1}, 30 \mathrm{~min}\right)$, centrifugation $(3,250 \times$ $g, 10 \mathrm{~min}$ ), filtering through a Whatman 42 filter paper and storage at $-20{ }^{\circ} \mathrm{C}$ to await analysis. Available soil $\mathrm{NO}_{3}{ }^{-}, \mathrm{NH}_{4}{ }^{+}$and $\mathrm{P}$ were determined colorimetrically on a PowerWave XS microplate spectrophotometer (BioTek UK, Bedfordshire, UK) using the methods of Mulvaney (1996), Miranda et al. (2001), and Murphy and Riley (1962) respectively. Available $\mathrm{K}$ in the acetic acid extracts was determined with a Model 410 flame photometer (Sherwood Scientific Ltd., Cambridge, UK). The moisture content of residue samples was determined by oven drying $\left(80{ }^{\circ} \mathrm{C}, 72 \mathrm{~h}\right.$ ), while total $\mathrm{C}$ and $\mathrm{N}$ was determined with a CHN2000 analyser (Leco Corp., St Joseph, MI, USA). 


\subsection{Experimental treatments}

The cores were randomly assigned to six treatments as follows: (1) Control, (2) Water

table maintained at $15 \mathrm{~cm}$ below the surface $\left(\mathrm{WT}_{15}\right)$, (3) Water table maintained at the soil

surface $\left(\mathrm{WT}_{0}\right)$, (4) Soil surface covered with horticultural fleece $\left(\mathrm{C}_{\text {fleece }}\right)$, (5) Simulated tillage

$140\left(\mathrm{~S}_{\text {till }}\right),(6)$ Crop residues applied to the soil surface $\left(\mathrm{CR}_{\text {surf }}\right)$, and (7) Soil tilled and crop

residues incorporated into the soil $\left(\mathrm{CR}_{\text {incorp }}\right)$ (Table 2). Each core had mesh covering the base

and was placed in larger plastic container to allow accurate water table control

(Supplementary information Appendix A, Fig. A.1). Sand surrounded the outside of the core

to minimise thermal gradients and holes drilled in the side of the containers to allow drainage, or maintenance of the water table in the $\mathrm{WT}_{0}$ and $\mathrm{WT}_{15}$ treatments. The mesocosms were laid out in a randomised block design with five replicates of each treatment, with blocks aligned

to the prevailing wind direction (SW-NE) to account for differences in sheltering and

evapotranspiration. Water tables were established by filling the containers with artificial rainwater solution (containing $96 \mu \mathrm{mol} \mathrm{L}{ }^{-1} \mathrm{NaCl}, 10 \mu \mathrm{mol} \mathrm{L}^{-1} \mathrm{~K}_{2} \mathrm{SO}_{4}, 5 \mu \mathrm{mol} \mathrm{L}{ }^{-1}$

$\mathrm{CaCl}_{2} \cdot 2 \mathrm{H}_{2} \mathrm{O}, 6 \mu \mathrm{mol} \mathrm{L} \mathrm{MgCl}_{2} \cdot 6 \mathrm{H}_{2} \mathrm{O}, 15 \mu \mathrm{mol} \mathrm{L} \mathrm{NH}_{4} \mathrm{NO}_{3}$, and $0.1 \mu \mathrm{mol} \mathrm{L} \mathrm{KH}_{2} \mathrm{PO}_{4}$, reflecting average Welsh rainwater composition; Stevens et al., 1997) until the excess ran out of the lateral drainage holes. Subsequently, water table height was maintained with natural or artificial rain water. For the $\mathrm{C}_{\text {fleece }}$ treatment, white horticultural, unwoven polypropylene fleece was secured over the top of the core headspace using plastic-coated wire. Horticultural fleece can be used for a variety of purposes including crop protection from frosts or pests and diseases, and soil warming and protection from wind or water erosion (e.g., Olle and Bender, 2010). At our study site, it is used primarily for soil warming and crop protection against frosts, to facilitate the production of early crops. Cultivation treatments were based on the typical ploughing depth at the field site $(\mathrm{c} .30-35 \mathrm{~cm}$ ), and were implemented by removing 
the whole volume of soil from the core, mixing in crop residues where appropriate, and packing loosely back into the core. Soil residue treatments involved the addition of Iceberg lettuce (Lactuca sativa L.) residues (c. $5 \times 5 \mathrm{~cm}$ pieces) to the soil based on rates measured in the field post-harvest ( $52 \%$ of the total crop; $0.9 \mathrm{t} \mathrm{Cha}^{-1}$ ). The residues were pressed into the soil surface to simulate post-harvest tractor traffic.

Mesocosm measurements were made for seven consecutive days following treatment application (May and Aug. 2013), then twice per week for two weeks, then weekly until the end of each experimental period (Aug. and Nov 2013). The experiment had two phases for the water table treatments $\left(\mathrm{WT}_{0}\right.$ and $\left.\mathrm{WT}_{15}\right)$ : Phase I involved maintaining the water table at the target depth for 3 months (i.e. 0 or $-15 \mathrm{~cm}$ ), while in Phase II the water table was lowered (by drilling holes in the base of the container) to match the control treatment (i.e. $-30 \mathrm{~cm}$ ). After 6 months, observable differences in GHG emissions among the water table treatments were largely negligible. Consequently, the cores were dismantled, split into $10 \mathrm{~cm}$ depth fractions and analysed as outlined in Section 2.3.

\subsection{Greenhouse gas monitoring}

Closed, non-vented static chambers were used to measure emissions of $\mathrm{CH}_{4}$ and $\mathrm{N}_{2} \mathrm{O}$. These consisted of white opaque polypropylene cylindrical chambers (headspace $0.66 \mathrm{dm}^{3}$ ) with a rubber septum sampling port in the lid (Supplementary information Appendix A, Fig. A.1). Each chamber was attached immediately before taking the first gas sample $\left(t=t_{0}\right)$, giving a final average enclosed headspace of $1.72 \mathrm{dm}^{3}$. Subsequent samples were taken at approximately 10 min intervals $\left(t=t_{10}, t_{20}\right.$ and $\left.t_{30}\right)$. Gas sampling and storage procedures and materials followed those described in Taft et al. (2017). Sample analysis was undertaken with a gas chromatograph (Varian 450-GC, Bruker UK Ltd., Coventry, UK), equipped with a flame ionisation detector (FID, operated at $120-125^{\circ} \mathrm{C}$ ) and electron capture detector (ECD, 
operated at $300{ }^{\circ} \mathrm{C}$ ), and attached to a QUMA QHSS1-40 Headspace Autosampler (QUMA

Electronik \& Analytik GmbH, Wuppertal, Germany), which injected $2 \mathrm{ml}$ of sample into the

GC. We measured $\mathrm{CO}_{2}$ emissions from the cores with an EGM-4 infra-red gas analyser (PP

Systems, Hitchin, UK) equipped with an SRC-1 soil respiration chamber.

\subsection{Soil water, climate and redox measurements}

Soil temperature was measured with a Checktemp $1^{\circledR}$ probe $\left( \pm 0.3^{\circ} \mathrm{C}\right.$; Hanna

Instruments Ltd, Leighton Buzzard, UK) over a 0-10 cm depth. Soil solutions were recovered

non-destructively throughout the experiment using Rhizon ${ }^{\circledR}$ soil water samplers (Rhizosphere

Research Products, Wageningen, The Netherlands) inserted into the topsoil $(0-10 \mathrm{~cm}$ depth$)$.

Soil solutions were stored at $-20{ }^{\circ} \mathrm{C}$ to await analysis. During experimental Phase II, soil

surface (1-2 cm depth) redox potential $\left(E_{\mathrm{h}}\right)$ was measured using an Eijkelkamp BNC glass

Platinum electrode with an $\mathrm{Ag} / \mathrm{AgCl}$ reference electrode and $3 \mathrm{M} \mathrm{KCl}$ electrolyte

(Eijkelkamp Agrisearch Equipment, Giesbeek, The Netherlands) following Eijkelkamp (2009). Sampling ports in the side of the core (at 10, 20 and $30 \mathrm{~cm}$ below the soil surface) allowed additional temperature and $E_{\mathrm{h}}$ measurements to be made. Rainwater samples were collected periodically through the experiment and analysed for soluble N. Meteorological data (rainfall, air temperature) were obtained from the local Met. Office monitoring station.

\subsection{Statistical analysis}

Statistical analyses were performed using SPSS v. 20 (IBM Corp., Armonk, NY),

with significance being accepted at $p \leq 0.05$ unless otherwise stated. GHG flux calculation and data cleaning procedures were identical to those of Taft et al. (2017). Cumulative flux estimates were converted to 100 -year global warming potential $\left(G W P_{100}\right) \mathrm{CO}_{2}$ equivalents ( $\mathrm{CO}_{2}$-e) according to IPCC (2006). Cumulative fluxes of $\mathrm{CO}_{2}, \mathrm{~N}_{2} \mathrm{O}, \mathrm{CH}_{4}$ and total $G W P_{100}$ 
for each treatment were compared using ANOVA, independent t-test, Kruskal-Wallis or

Kolmogorov-Smirnov Z tests as appropriate. Post-Hoc tests were conducted to determine significantly different treatments using Tukey's HSD, Gambrell-Howell, or KolmogorovSmirnov Z statistics (with Bonferroni correction for multiple comparisons) as appropriate. Relationships among individual GHGs, temperature, rainfall, and soil $\mathrm{N}$ concentrations were explored using Kendall's tau statistic $(\tau)$.

All statistical analyses were performed separately on the water table group of treatments (Control vs. $\mathrm{WT}_{0}$ vs. $\left.\mathrm{WT}_{15}\right)$, the fleece treatment (Control vs. $\mathrm{C}_{\text {fleece }}$ ), and the cultivation and residue group of treatments (Control vs. $\mathrm{S}_{\text {till }}$ vs. $\mathrm{CR}_{\text {surf }}$ vs. $\mathrm{CR}_{\text {incorp }}$ ). Normality was tested using the Shapiro-Wilk test (Field, 2005), and non-normal data were $\log _{10^{-}}$ transformed or square-root transformed; where transformation was ineffective, or where heterogeneity of variances was observed (Levene's or Welch's test statistic), appropriate nonparametric tests were used to compare medians of those data groups. Soil physical and chemical characteristics for each soil depth layer were compared using ANOVA or the independent t-test, or Kruskall-Wallis or Kolmogorov-Smirnov Z tests for data deviating greatly from normality or homogeneity of variances. Significant effects of treatment and time (each treatment including the control, compared to the baseline) were tested.

\section{Results}

\subsection{Climate and changes in soil quality}

Analysis of the soil at the end of the experiment showed that some properties had changed slightly over the 6-month period (Table 1). In most cases, however, the effect of treatment was small. The mean air temperature for Phase I and II of the experiment were 15.4 and $13.2^{\circ} \mathrm{C}$, respectively (Fig. 1a-b). During the same period, the cumulative rainfall was 191 and $229 \mathrm{~mm}$, respectively. 


\subsection{Effect of water table manipulation on GHG emissions and soil chemistry}

Soil respiration responded rapidly to raising of the water table, falling close to zero

within $5 \mathrm{~d}$ of water table raising in the $\mathrm{WT}_{0}$ treatment, and remaining lower $(11 \pm 1.4 \mathrm{mg}$

$\left.\mathrm{CO}_{2}-\mathrm{C} \mathrm{m}^{-2} \mathrm{~h}^{-1}\right)$ than mean fluxes from the control and $\mathrm{WT}_{15}$ treatments $\left(76 \pm 3.6 \mathrm{mg} \mathrm{CO}_{2}-\mathrm{C}\right.$ $\mathrm{m}^{-2} \mathrm{~h}^{-1}$ and $78 \pm 3.9 \mathrm{mg} \mathrm{CO}_{2}-\mathrm{C} \mathrm{m}^{-2} \mathrm{~h}^{-1}$ respectively) for the remainder of the wetted period

(Fig. 1c-d). Immediately after draining, there was a peak in $\mathrm{CO}_{2}$ emissions from both the

$\mathrm{WT}_{0}$ and $\mathrm{WT}_{15}$ treatments, however, these returned to values close to the control after a further $44 \mathrm{~d}$.

During the wetted period, mean $\mathrm{N}_{2} \mathrm{O}$ emissions ranged from $5.0 \pm 6.0$ to $4453 \pm 577$ $\mu \mathrm{g} \mathrm{N}_{2} \mathrm{O}-\mathrm{N} \mathrm{m}^{-2} \mathrm{~h}^{-1}$ across all treatments (Fig. 1e-f). A substantial peak $\left(4453 \pm 577 \mu \mathrm{g} \mathrm{N} \mathrm{N}_{2} \mathrm{O}-\mathrm{N}\right.$ $\mathrm{m}^{-2} \mathrm{~h}^{-1}$ ) was observed from the $\mathrm{WT}_{15}$ treatment after $14 \mathrm{~d}$ and emissions in this treatment remained consistently higher than the $\mathrm{WT}_{0}$ and control treatments during the first six weeks.

Over this period, $\mathrm{N}_{2} \mathrm{O}$ emissions were very similar in the control and $\mathrm{WT}_{0}$ treatments.

Drainage resulted in a short-lived rise (c. 14 d) in $\mathrm{N}_{2} \mathrm{O}$ flux which was most pronounced in the $\mathrm{WT}_{15}$ treatment immediately following draining $\left(1506 \pm 499 \mu \mathrm{g} \mathrm{N}_{2} \mathrm{O}-\mathrm{N} \mathrm{m}^{-2} \mathrm{~h}^{-1}\right)$.

Emissions in the $\mathrm{WT}_{0}$ treatment exhibited a similar but smaller response $3 \mathrm{~d}$ after draining $\left(699 \pm 277 \mu \mathrm{g} \mathrm{N}_{2} \mathrm{O}-\mathrm{N} \mathrm{m}^{-2} \mathrm{~h}^{-1}\right)$. Fluxes of $\mathrm{CH}_{4}$ remained low throughout the experiment (Fig. 1g-h).

Cumulative GHG emissions were significantly influenced by water table depth (Table 3). In the initial wetted phase (Phase I), a significant decline in $\mathrm{CO}_{2}$ emissions was apparent as the water table was raised closer to the soil surface. However, a significant difference was only observed between the control and $\mathrm{WT}_{0}$ treatments $(p<0.01)$, although the difference between the $\mathrm{WT}_{15}$ and $\mathrm{WT}_{0}$ treatments was almost significant $(p=0.08)$. Cumulative $\mathrm{N}_{2} \mathrm{O}$ emission was significantly influenced by water table depth $(p<0.001)$, with the mean $\mathrm{WT}_{15}$ 
cumulative flux being significantly higher than both the control and $\mathrm{WT}_{0}$ treatments (both $p<$ 0.001). No significant treatment effects were observed for cumulative $\mathrm{CH}_{4}$ emissions.

262

Cumulative $G W P_{100}$ for water table treatments was significantly different among groups ( $p<$ 0.001); with a highly significant increase in the order $\mathrm{WT}_{0}<$ control $<\mathrm{WT}_{15}$ (all $p<0.001$ ).

In the drained period (Phase II), significant differences were recorded for median $\mathrm{CO}_{2}$ emissions among water table groups ( $p<0.05$; Table 3). However, no significant differences were found among the three water table treatments for cumulative $\mathrm{N}_{2} \mathrm{O}$, cumulative $\mathrm{CH}_{4}$, or $G W P_{100}$.

Over the entire experiment (Phase I and Phase II), $\mathrm{CO}_{2}$ and $\mathrm{N}_{2} \mathrm{O}$ emissions were highly influenced by water table depth (both $p<0.001$; Table 3). There was a highly significant decline in soil respiration between $\mathrm{WT}_{15}$ and $\mathrm{WT}_{0}$ treatments $(p<0.001)$, while no difference was noted between the control and $\mathrm{WT}_{15}$ treatments. Mean $\mathrm{N}_{2} \mathrm{O}$ emissions were significantly higher from the $\mathrm{WT}_{15}$ treatment compared to the control and $\mathrm{WT}_{0}$ treatments (both $p<0.001$ ). There was no effect of water table depth on cumulative $\mathrm{CH}_{4}$ emissions. Water table treatment had a highly significant effect on $G W P_{100}(p<0.001$; Table 3$)$, and all treatments were significantly different to each other: $\mathrm{WT}_{0}$ was lower than both the control and $\mathrm{WT}_{15}$ treatments $(p<0.05$ and $p<0.001$ respectively), and the control was lower than $\mathrm{WT}_{15}(p<0.001)$.

Mean $\mathrm{NO}_{3}{ }^{-}$concentrations were substantially lower in the $\mathrm{WT}_{0}$ than in the control and $\mathrm{WT}_{15}$ treatments, both of which were similar to each other (Fig. 1i-j). Dissolved $\mathrm{NH}_{4}{ }^{+}$ remained consistently low at all measurement times (Fig. 1k-1).

Redox $\left(E_{\mathrm{h}}\right)$ values in the upper soil layer was similar across all treatments remaining $>400 \mathrm{mV}$ for most of the monitoring period (Fig. 2a). On the day on which the cores were drained, the $E_{\mathrm{h}}$ was notably lower in the $10 \mathrm{~cm}$ soil layer $\mathrm{WT}_{0}$ treatment $(369 \pm 36 \mathrm{mV})$ than in the $\mathrm{WT}_{15}$ and control treatments ( $480 \pm 11$ and $487 \pm 10 \mathrm{mV}$, respectively; Fig. 2b). Upon 
draining, an immediate and marked drop in $E_{\mathrm{h}}$ was observed in the $20 \mathrm{~cm}$ soil layer in both the $\mathrm{WT}_{0}(315 \pm 46 \mathrm{mV})$ and $\mathrm{WT}_{15}(422 \pm 42 \mathrm{mV})$ cores, compared with the control $(490 \pm 8$ $\mathrm{mV}$, Fig. 2c). Four days after draining, however, there were no observable differences among treatments. Redox potentials in the $30 \mathrm{~cm}$ soil layer were the most responsive to water table treatments (Fig. 2d). Both $\mathrm{WT}_{0}$ and $\mathrm{WT}_{15}$ treatments showed substantially lower mean $E_{\mathrm{h}}$ values $(218 \pm 17 \mathrm{mV}$ and $227 \pm 19 \mathrm{mV}$, respectively) compared with the control cores $(341 \pm$ $24 \mathrm{mV}$ ) for the first $38 \mathrm{~d}$. By day $62, \mathrm{WT}_{15}$ redox values had returned to that of the control values, whereas the $\mathrm{WT}_{0} E_{\mathrm{h}}$ took $85 \mathrm{~d}$ to recover to levels seen in the control.

\subsection{Effect of fleece application on GHG emissions and soil chemistry}

Soil respiration from the $\mathrm{C}_{\text {fleece }}$ and control cores followed a similar pattern throughout the experiment although the fluxes were generally higher in the $\mathrm{C}_{\text {fleece }}$ treatment (Fig. 3b). The peak flux in the $\mathrm{C}_{\text {fleece }}$ treatment $\left(232 \pm 61 \mathrm{mg} \mathrm{CO}_{2}-\mathrm{C} \mathrm{m}^{-2} \mathrm{~h}^{-1}\right)$ occurred on day 52 , and was almost double that of the control emission $\left(132 \pm 6.6 \mathrm{mg} \mathrm{CO}_{2}-\mathrm{C} \mathrm{m}^{-2} \mathrm{~h}^{-1}\right)$. Mean $\mathrm{N}_{2} \mathrm{O}$ emissions were similar from the $\mathrm{C}_{\text {fleece }}$ and control treatments throughout most of the experimental period (Fig. 3c). Maximum $\mathrm{N}_{2} \mathrm{O}$ emission from the $\mathrm{C}_{\text {fleece }}$ treatment $(542 \pm 182$ $\mu \mathrm{g} \mathrm{N} \mathrm{N}_{2} \mathrm{O}-\mathrm{N} \mathrm{m}^{-2} \mathrm{~h}^{-1}$ ) occurred $7 \mathrm{~d}$ after fleece application, returning to control levels after $14 \mathrm{~d}$. Emissions of $\mathrm{CH}_{4}$ were higher than in the control treatment, however, these fluxes were still very low (Fig. 3d). Mean $\mathrm{C}_{\text {fleece }} \mathrm{NO}_{3}-\mathrm{N}$ and $\mathrm{NH}_{4}-\mathrm{N}$ concentrations were very similar to the control treatment on all sampling dates (Figs. 3e-f).

Overall, cores with fleece had significantly higher mean cumulative $\mathrm{CO}_{2}$ emissions ( $p$ $<0.05$; Table 3) while total $\mathrm{N}_{2} \mathrm{O}$ emission was also higher than the control $(p=0.06)$. The fleece treatment had a significantly greater cumulative $G W P_{100}$ emission than the control $(p<$ $0.01)$. 


\subsection{Effect of cultivation tillage on GHG emissions and soil chemistry}

Mean $\mathrm{CO}_{2}$ fluxes in the tilled soil were very similar to the control on most sampling dates, ranging from $26 \pm 4.7$ to $135 \pm 5.2 \mathrm{mg} \mathrm{CO}_{2}-\mathrm{C} \mathrm{m}^{-2} \mathrm{~h}^{-1}$ (Fig. 4d). A marked peak in $\mathrm{CO}_{2}$ release was observed immediately after simulated ploughing, however, this was of short duration. For a few days during the experiment, $\mathrm{S}_{\text {till }} \mathrm{CO}_{2}$ emissions were lower than in the control cores. Overall, mean fluxes of $\mathrm{N}_{2} \mathrm{O}$ and $\mathrm{CH}_{4}$ were similar to the control (Figs. $4 \mathrm{~g}$ and 4j). Ploughing had no significant effect when compared to undisturbed soil on cumulative individual GHG emissions or overall $G W P_{100}$ (Table 3). We observed no consistent effect of tillage on soluble $\mathrm{N}$ concentrations relative to the control throughout the experiment.

\subsection{Effect of residue incorporation on $G H G$ emissions and soil chemistry}

Both residue treatments showed a marked increase in soil respiration immediately

following surface application or incorporation into the soil, with elevated levels persisting for three weeks after application (Fig. 4e-f). The response was generally lower when residues were incorporated into the soil. Emissions of $\mathrm{N}_{2} \mathrm{O}$ responded positively to residue application, but with a slower response (5-6 d), and over a longer period (37 d), compared to the control treatment (Fig. 4h-i). In the $\mathrm{CR}_{\text {incorp }}$ treatment, both soil respiration and $\mathrm{N}_{2} \mathrm{O}$ emissions were lower than from the control towards the end of the experimental period. No marked effect of residue treatment was observed for $\mathrm{CH}_{4}$ emissions or soil solution $\mathrm{N}$ relative to the control throughout the experiment (Figs. 4k-1, 4n-o and 4q-p).

The surface-applied residue treatment yielded a significantly higher mean cumulative soil respiration $(p<0.01)$, mean cumulative $\mathrm{N}_{2} \mathrm{O}$ emission $(p<0.05)$, and median cumulative $G W P_{100}(p<0.01)$ than the control treatment (Table 3). In contrast, no significant differences were apparent in any of the individual cumulative GHG emissions or overall $G W P_{100}$ between the control and residue incorporation treatment (Table 3). Compared to the surface- 
residue application treatment, cumulative emissions from the incorporated residue treatment were only significantly lower for $\mathrm{CO}_{2}(p<0.05)$.

\subsection{Effect of soil and weather conditions on GHG emissions}

Redox potential at depth was significantly correlated with $\mathrm{CO}_{2}(p<0.05)$ and $\mathrm{N}_{2} \mathrm{O}(p$ $<0.05)$ emissions, but not $\mathrm{CH}_{4}$ release $(p>0.05)$ (Table 4). At $20 \mathrm{~cm}$ below the soil surface, $E_{\mathrm{h}}$ was positively associated with $\mathrm{CO}_{2}$ emission in the control and $\mathrm{WT}_{15}$ treatments, explaining $3 \%$ of the variability in soil respiration $(\tau=-0.176$ to -0.179$)$. At $30 \mathrm{~cm}$ depth, $E_{\mathrm{h}}$ was negatively associated with $\mathrm{CO}_{2}$ emission in the $\mathrm{WT}_{0}$ treatment, and $\mathrm{N}_{2} \mathrm{O}$ emission in the $\mathrm{WT}_{0}$ and $\mathrm{WT}_{15}$ treatments, explaining $3 \%$ of $\mathrm{CO}_{2}$ emission variability and 3-6\% of $\mathrm{N}_{2} \mathrm{O}$ emission variability $(\tau=-0.174$ to -0.254$)$.

Soil temperature, mean daily air temperature, and measured air temperature were positive, highly significant predictors of soil respiration within most treatments, accounting for between $12-31 \%, 3-38 \%$, and $5-18 \%$ of fluxes respectively $(\tau=0.341$ to $0.559, p<0.05$ to $<0.01$; Table 4). Temperature variables were less suitable for predicting $\mathrm{N}_{2} \mathrm{O}$ emissions, although some highly significant correlations were still apparent. Soil temperature, mean daily air temperature, and measured air temperature at the time of sampling predicted $2-10 \%$, $3-7 \%$, and 3-12\% of $\mathrm{N}_{2} \mathrm{O}$ emissions respectively ( $\tau=0.147$ to $0.313, p<0.05$ to $<0.001$ ).

Daily and 5-day rainfall (cumulative rainfall from the day of measurement and the four preceding days) were negative highly significant predictors of $\mathrm{CO}_{2}$ emissions for most of the treatments $(\tau=-0.112$ to $-0.460 ; p<0.05$ to $<0.001)$, while daily rainfall was positively significantly correlated with surface-applied residue $\mathrm{CO}_{2}$ efflux $(\tau=0.180, \mathrm{p}<0.05$; Table 4). Daily rainfall explained 1-8\% and 5-day rainfall explained 2-21\% of soil respiration.

Emissions of $\mathrm{N}_{2} \mathrm{O}$ and daily rainfall were highly significantly negatively correlated in all but the drained control treatment, accounting for $2-34 \%$ of emissions $(\tau=-0.136$ to $-0.579, p<$ 
0.05 to $<0.001)$. Cumulative 5-day rainfall was a significant predictor of $\mathrm{N}_{2} \mathrm{O}$ emission in the $\mathrm{WT}_{15}$ treatment only, explaining $4-7 \%$ of $\mathrm{N}_{2} \mathrm{O}$ flux $(\tau=-0.199$ to $-0.260 ; p<0.001)$. Dissolved $\mathrm{N}$ was a significant predictor of soil respiration in most treatments.

Emissions of $\mathrm{N}_{2} \mathrm{O}$ and $\mathrm{NO}_{3}{ }^{-}$concentration were significantly positively correlated in the control (Phase I) and $\mathrm{WT}_{15}$ (Phase II, Phase I + II) treatments, with $\mathrm{NO}_{3}{ }^{-}$accounting for 3$13 \%$ of variability in $\mathrm{N}_{2} \mathrm{O}$ emission $(\tau=0.185$ to $0.358, p<0.05$ to $<0.001)$. Concentrations of $\mathrm{NH}_{4}{ }^{+}$were positively associated with soil respiration in the control (Phase I), $\mathrm{WT}_{15}$ (Phase I, Phase I + II), and $\mathrm{S}_{\text {till }}$ treatments (2-7\% of variability, $\tau=0.135$ to $0.255, p<0.05$ to $<$ 0.01), but negatively associated with soil respiration in the control (Phase II) treatment (3\% of variability, $\tau=-0.187, p<0.05)$. A significant correlation between dissolved $\mathrm{NH}_{4}^{+}$ concentration and $\mathrm{N}_{2} \mathrm{O}$ emission was found in only the surface-applied residue treatment (9\% of variability, $\tau=-0.292, p<0.01$ ), and with $\mathrm{CH}_{4}$ emissions in the fleece treatment $(6 \%$ of variability, $\tau=-0.239, p<0.01$; Table 4$)$.

\section{Discussion}

\subsection{Effect of water table manipulation on GHG emissions}

In agreement with previous studies of fen and blanket peats under a range of land uses, raising the water table in this study reduced $\mathrm{CO}_{2}$ emissions, moreover, the magnitude of the reduction proved highly sensitive to water table depth (Dinsmore et al., 2009; Freeman et al., 1993; Lloyd, 2006; Kechavarzi et al., 2007). Maintaining the water table at the surface also reduced $\mathrm{N}_{2} \mathrm{O}$ emissions. We ascribe this to a reduction in the nitrification rate and $\mathrm{NO}_{3}{ }^{-}$ production and the complete denitrification of any $\mathrm{NO}_{3}{ }^{-}$present to $\mathrm{N}_{2}$ (Velthof and Oenema, 1997). Lowering the water table to $15 \mathrm{~cm}$, however, resulted in greatly elevated $\mathrm{N}_{2} \mathrm{O}$ emissions. This concurs with findings from Freeman et al. (1993) who also reported $\mathrm{N}_{2} \mathrm{O}$ emission to be inversely correlated with water table depth. Our highest rate of $\mathrm{N}_{2} \mathrm{O}$ emission 

in the water table treatments $\left(4.5 \mathrm{mg} \mathrm{N}_{2} \mathrm{O}-\mathrm{N} \mathrm{m}^{-2} \mathrm{~h}^{-1}\right)$ was two orders of magnitude higher than emissions from semi-natural peatland mesocosms observed by Freeman et al. (1993) and

387

Dinsmore et al. (2009), but similar to studies of arable peatlands (Flessa et al., 1998; Taft et al., 2017; Weslien et al., 2012). A large initial peak in $\mathrm{N}_{2} \mathrm{O}$ emissions was observed in the $\mathrm{WT}_{15}$ treatment after raising the water table, while only a small pulse was seen in the $\mathrm{WT}_{0}$ treatment. Conversely, the $\mathrm{WT}_{0}$ treatment released most $\mathrm{N}_{2} \mathrm{O}$ after draining, while the $\mathrm{N}_{2} \mathrm{O}$ pulse from the $\mathrm{WT}_{15}$ treatment was smaller. These relatively rapid, short-lived, strong responses to wetting and draining events in peat soils are common, with their magnitude typically limited by soil moisture and soluble N (Li et al., 1992). Overall, there was no marked effect of water table treatment on $\mathrm{CH}_{4}$ production over the wetted or drained experimental periods, contrary to the general trend of water table raising increasing emissions (Bussell et al., 2010). Strictly anaerobic conditions required for substantial $\mathrm{CH}_{4}$ emissions, however, may take a long time to develop (>1 y; Oomes et al., 1997), and in infrequently flooded soils are typically found at lower profile depths than those sampled in this study (Mitsch and Gosselink, 2000). The low rates of $\mathrm{CH}_{4}$ release could also be due to a lack of methanogens, or the abundance of alternative electron acceptors and/or an efficient population of methanotrophs in the topsoil. This is supported by measured redox values which largely fell within the range associated with $\mathrm{CO}_{2}$ production and $\mathrm{CH}_{4}$ consumption (400 to $500 \mathrm{mV}$ ) and $\mathrm{N}_{2} \mathrm{O}$ production (200 to $500 \mathrm{mV}$ ), but not for $\mathrm{CH}_{4}$ production (-100 to 200 mV; Le Mer and Roger, 2001; Li, 2007; Mitsch and Gosselink, 2000).

This study simulated raising the water table during late spring followed by draining in late summer, mimicking the water management regime commonly employed by farms in the study area to enable sub-surface irrigation and minimise peat loss via wind erosion (Dawson et al., 2010). In practice, raising the water table to within $15 \mathrm{~cm}$ of the soil surface would not be implemented while a crop was in place, as it would likely result in high crop mortality and 
be unsuitable for field traffic. Instead, this intervention would probably be implemented between summer crops, possibly over quite short fallow periods. The relative efficacy of flooding as a GHG mitigation strategy may be enhanced by additional impacts such as weed growth even during relatively short fallow periods; which could further reduce net $G W P_{100}$ through elevated net primary productivity and plant removal of $\mathrm{NO}_{3}^{-}$(e.g., Kløve et al., 2017). Conversely, both the presence of weeds and labile organic matter input from postharvest crop residues could result in substantial emissions of $\mathrm{N}_{2} \mathrm{O}$ and $\mathrm{CH}_{4}$ (Le Mer and Roger, 2001). The net effect of vegetation therefore merits further investigation. Maintaining the water table at the correct level and ensuring it drains freely postflooding could be challenging. Kechavarzi et al. (2007) suggest that close spacing of subsurface drainage pipes $(\leq 10 \mathrm{~m})$ would be required to maintain a consistent water table level in a sub-irrigated field. Some fields are not equipped with closely spaced drainage pipes, and not all peat soils are sub-irrigated. Fluctuation of the water level between $0-15 \mathrm{~cm}$ of the soil surface, either through poor water level maintenance or slow drainage post-flooding, is likely to result in large pulses of GHGs, as was observed in the $\mathrm{WT}_{15}$ treatment, entirely negating the beneficial effect of flooding. This effect may be minimised if draining is undertaken in cooler weather. Further, flooding poses a number of difficulties both agronomically and in the context of the wider landscape. Implementation would require careful timing so that after flooding, soil had time to dry sufficiently before subsequent in-field machinery operations. Yields of subsequent crops could be reduced after flooding, or the costs of mineral fertiliser increased: our results strongly imply that much of the soil nitrate was leached from the soil columns during draining. In terms of wider landscape effects, leaching of nitrate into watercourses poses a severe pollution risk, with associated costs for the grower. Further, if flooding were to be implemented on a widespread scale, regulation would be required to 
ensure that it did not adversely impact on flood risk and response across the region, which would be challenging across areas of flat topography.

\subsection{Effect of fleece application on $G H G$ emissions}

This study found that fleece application significantly increased $G W P_{100}, \mathrm{CO}_{2}$ release and $\mathrm{N}_{2} \mathrm{O}$ emissions from soil. Fleece application is known to stabilise variations in soil temperature and to reduce soil moisture loss (Hamouz et al., 2006; 2005; Siwek et al., 2013; 2012). In this study, temperature was the strongest predictor of soil respiration, showing a significant positive correlation in the fleece-enclosed cores. This is consistent with other studies on the effect of temperature on peat soil respiration (Estop-Aragonés and Blodau, 2012; Maljanen et al., 2002). Soil temperature has also been shown to positively correlate with $\mathrm{N}_{2} \mathrm{O}$ emissions (Maljanen et al., 2002), although in this study the relationship was not strong.

The greatest emissions from the fleece treatment were observed when the air temperature was highest. In practice, fleece would usually only be applied to early crops, to minimise the risk of frost damage and encourage early crop development (Hamouz et al., 2006). However, the presence of fleece did increase net emissions under cooler as well as warmer temperatures, albeit at a reduced rate. It is important therefore, to restrict fleece application to as short a period as possible during cooler weather, as is common under current practice (G's Fresh, pers. comm.; HDC, 2006).

As with the water table treatments, the effect of prolonged fleece application in the presence of a crop should be investigated at the field scale, to compare crop growth and associated net ecosystem exchange between fleece and control treatments, as this may further reduce the difference in emissions. It would also be of interest to consider the effect on net emissions when fleece is applied over recently-fertilised peat, since the results suggest that 
$\mathrm{N}_{2} \mathrm{O}$ emissions may substantially increase when fertilised soil is subjected to the warmer soil temperatures associated with fleece application.

\subsection{Effect of tillage on $G H G$ emissions}

Simulated ploughing resulted in an immediate, small and short-lived peak in soil respiration but a negligible response of $\mathrm{N}_{2} \mathrm{O}$. Ploughing-induced peaks in $\mathrm{CO}_{2}$ emission from cultivated Histosols have been noted by Elder and Lal (2008) and Reicosky et al. (2008), although the response found in our study was several-fold lower than that of Elder and Lal (2008) (625 mg CO $2-\mathrm{C} \mathrm{m}^{-2} \mathrm{~h}^{-1}$ ). Mean emissions from a bare-tilled peat measured by Maljanen et al. (2002) (300 $\mathrm{mg} \mathrm{CO}_{2}-\mathrm{C} \mathrm{m}^{-2} \mathrm{~h}^{-1}$ ), were also higher than the peak emission of $135 \mathrm{mg} \mathrm{CO}_{2}-\mathrm{C} \mathrm{m}^{-2} \mathrm{~h}^{-1}$ recorded in this study. Production of $\mathrm{N}_{2} \mathrm{O}$ was not stimulated by a ploughing event. This contrasts with the findings of Elder and Lal (2008), however Maljanen et al. (2002) and Weslien et al. (2012) also reported negligible effects of ploughing on $\mathrm{N}_{2} \mathrm{O}$ emissions. It is probable that the considerably lower peak of $\mathrm{N}_{2} \mathrm{O}$ emissions observed here compared with those of Elder and Lal (2008) are a result of suboptimal soil moisture conditions inhibiting $\mathrm{N}_{2} \mathrm{O}$ production, owing to the comparatively good drainage and lower bulk density of our tilled cores (Dalal et al., 2003). Our results are in strong contrast to the assertion that cultivation results in a large efflux of both $\mathrm{CO}_{2}$ and $\mathrm{N}_{2} \mathrm{O}$ (Dawson and Smith, 2007; Kasimir-Klemedtsson et al., 1997). This suggests that adoption of minimum or zero tillage practices may not help preserve soil $\mathrm{C}$ on sites with a long history of cultivation.

\subsection{Effect of residue application on GHG emissions}

The pattern and magnitude of $\mathrm{CO}_{2}$ and $\mathrm{N}_{2} \mathrm{O}$ fluxes observed after residue application may be attributed in part to the characteristics and amount of, and mechanism by which, the residues were added. In a study comparing emissions from soils amended with crop residues 
with differing compositions, Velthof et al. (2002) observed a rapid response and pronounced peak in $\mathrm{N}_{2} \mathrm{O}$ and $\mathrm{CO}_{2}$ emissions from crops which, similarly to this study, had a low $\mathrm{C} / \mathrm{N}$ ratio (c. 10-20) and high moisture content (>80\%). Other studies support the theory that the application of crop residues with low $\mathrm{C} / \mathrm{N}$ ratios tends to induce greater $\mathrm{CO}_{2}$ and $\mathrm{N}_{2} \mathrm{O}$ emissions (Loecke and Robertson, 2009), as well as biodegrading faster (Henderson et al., 2010). The emissions observed in our study were lower than expected, and may be explained by the relatively low total quantity of residue $\mathrm{C}$ and $\mathrm{N}$ added to each core $\left(746 \mathrm{mg} \mathrm{C}\right.$ core $^{-1}$, $73 \mathrm{mg} \mathrm{N}$ core $^{-1}$ ) in comparison with other studies (e.g., Velthof et al., 2002).

Residue application increased cumulative net emissions. This could be attributable to the positive priming of soil microbial activity and loss of native SOM (Kuzyakov et al., 2000; Kuzyakov, 2010). Although we cannot discount this mechanism, our data does not support it for the following reasons: (1) Compared to the control, the extra loss of $\mathrm{CO}_{2}$ was only equivalent to $0.32 \mathrm{t} \mathrm{Cha}^{-1}$ ( $\left.\mathrm{CR}_{\text {surf }}\right)$ and $0.01 \mathrm{t} \mathrm{Cha}^{-1}$ ( $\left.\mathrm{CR}_{\text {incorp }}\right)$, i.e. considerably less than the quantity of residue-C added to the cores $\left(0.90 \mathrm{t} \mathrm{C} \mathrm{ha}^{-1}\right)$. This suggests that negative priming may actually be occurring, particularly when residues are incorporated into the soil, although further work would be needed to confirm this; (2) The equivalent of $88 \mathrm{~kg} \mathrm{~N}$ was added to the residue cores, but only 2.1 and $0.7 \mathrm{~kg} \mathrm{~N}_{2} \mathrm{O}-\mathrm{N} \mathrm{ha}^{-1}$ more than the control was lost in the surface applied and incorporation treatments respectively. It should be noted, however, that we cannot account for denitrification losses of $\mathrm{N}_{2}$; (3) We had expected that if positive priming was occurring the effects would be greater when the residues were incorporated into the soil; and (4) Recent research suggests that much of the $\mathrm{CO}_{2}$ released from plant residues applied to soil originates from the residue itself (e.g., cell autolysis) rather than from a soil microbial-induced breakdown of the residues (Marella et al., 2017).

While residue incorporation resulted in lower emissions relative to surface application in our study, our experiment was limited to a single crop (lettuce). Characteristics such as 
509

510

511

512

513

crop dry matter content, $\mathrm{C} / \mathrm{N}$ ratio, availability of labile $\mathrm{C}$ and $\mathrm{N}$, and the total quantity of residue applied and its particle size distribution across or within the soil can significantly impact net emissions associated with residue application of different crops (Loecke and Robertson, 2009; Velthof et al., 2002; Webb et al., 2014). Further research might therefore focus on relative emissions from surface applied and incorporated residues of a range of crops at the field scale, and at a variety of points in the growing season (to account for the common practice of multiple cropping on these soils; Taft et al., 2017).

\section{Conclusions and implications}

The results of this study suggest that the relative efficacy of potential GHG mitigation options will be strongly influenced by the weather and soil conditions at the time of implementation, and hold the greatest potential efficacy if applied during the main growing season when GHG emissions are greatest. Net GHG emissions from the horticultural peat soils in this study proved sensitive to water table depth, with flooding to the soil surface being highly effective in reducing GHG emissions. However, avoiding a shallow water table is paramount in minimising emissions. Our study suggests that horticultural fleece should be used for the shortest possible period, and in cool weather only. Contrary to expectation, tillage did not significantly increase net GHG emissions. We recommend that tillage and harvesting operations should be conducted during cooler or damper weather to minimise the small peak in emissions. The impacts of lettuce residue treatment were somewhat inconclusive, with residue incorporation reducing net emissions compared to surface application, but only significantly for $\mathrm{CO}_{2}$ emissions and not for overall $G W P_{100}$.

The practical implications of implementation are dependent on synchronising measures with on-going management operations. Precise management of water table height is highly restricted from a practical perspective, and cannot be expected across large-scale 
534

535

536

537

538

539

540

541

542

543

544

545

546

547

548

549

550

551

552

553

554

555

556

557

areas, as this type of mitigation risks creating within-field emission hotspots. Conducting

tillage operations during cooler weather is likely to be somewhat impractical in relation to harvesting operations due to economic pressures. In contrast, restricting horticultural fleece use to the start of the season should pose few practical difficulties as the practice already aligns with current management. Our results suggest that no one single mitigation measure may be effective in reducing the rate of soil loss in cultivated peatlands. This has important implications for the practicalities of co-implementing individual mitigation strategies, or in considering more radical changes of land use and management in future.

\section{Acknowledgements}

This work was funded by the European Union's Knowledge Economy Skills Scholarships programme, in partnership with Footprints4Food and the Natural Environment Research

Council under the Soil Security Programme (Ref. NE/P014097/1). We would like to thank

Prof. Sue Page at the University of Leicester and Dr. Ed Moorhouse and Martin Hammond at G's Fresh for their scientific and technical input to the research.

\section{References}

Bussell, J., Jones, D.L., Healey, J.R., Pullin, A.S., 2010. How do draining and re-wetting affect carbon stores and greenhouse gas fluxes in peatland soils? CEE Review 08-012. Centre for Evidence-Based Conservation, Bangor University, UK. Available at: http://www.environmentalevidence.org/wp-content/uploads/2014/09/SR49.pdf (accessed March 2018).

Cannell, M.G.R., Milne, R., Hargreaves, K.J., Brown, T.A.W., Cruickshank, M.M., Bradley, R.I., Spencer, T., Hope, D., Billett, M.F., Adger, W.N., Subak, S., 1999. National 
inventories of terrestrial carbon sources and sinks: The UK experience. Clim. Change 42, 505-530. doi: https://doi.org/10.1023/A:1005425807434

Dalal, R.C., Wang, W.J., Robertson, G.P., Parton, W.J., 2003. Nitrous oxide emission from Australian agricultural lands and mitigation options: A review. Aust. J. Soil Res. 41, 165-195. doi: https://doi.org/10.1071/SR02064

Dalal, R.C., Allen, D.E., Livesley, S.J., Richards, G., 2008. Magnitude and biophysical regulators of methane emission and consumption in the Australian agricultural, forest, and submerged landscapes: A review. Plant Soil 309, 43-76. doi: https://doi.org/10.1007/s11104-007-9446-7

Dawson, J.J.C., Smith, P., 2007. Carbon losses from soil and its consequences for land-use management. Sci. Total Environ. 382, 165-190. doi: https://doi.org/10.1016/j.scitotenv.2007.03.023.

Dawson, Q., Kechavarzi, C., Leeds-Harrison, P.B., Burton, R.G.O., 2010. Subsidence and degradation of agricultural peatlands in the Fenlands of Norfolk, UK. Geoderma 154, 181-187. doi: https://doi.org/10.1016/j.geoderma.2009.09.017

Dinsmore, K.J., Skiba, U., Billett, M.F., Rees, R.M., 2009. Effect of water table on greenhouse gas emissions from peatland mesocosms. Plant Soil 318, 229-242. doi: https://doi.org/10.1007/s11104-008-9832-9

Eijkelkamp, 2009. Redox measuring equipment. Operating instructions. Eijkelkamp Agrisearch Equipment, Giesbeek, The Netherlands.

Elder, J.W., Lal, R., 2008. Tillage effects on gaseous emissions from an intensively farmed organic soil in North Central Ohio. Soil Tillage Res. 98, 45-55. doi: https://doi.org/10.1016/j.still.2007.10.003 
581 Estop-Aragonés, C., Blodau, C., 2012. Effects of experimental drying intensity and duration

582

583

584

585

586

587

588

589

590

591

592

593

594

595

596

597

598

599

600

601

602

603

604

605

on respiration and methane production recovery in fen peat incubations. Soil Biol.

Biochem. 47, 1-9. doi: https://doi.org/10.1016/j.soilbio.2011.12.008

FAO, 2006. World reference base for soil resources 2006: A framework for international classification, correlation and communication. World Soil Resources Reports 103. Food and Agriculture Organization of the United Nations, Rome, Italy. Available at: http://www.fao.org/3/a-a0510e.pdf (accessed March 2018).

Field, A., 2005. Discovering Statistics Using SPSS, Second ed., Sage Publications Ltd., Thousand Oaks, CA, USA.

Flessa, H., Wild, U., Klemisch, M., Pfadenhauer, J., 1998. Nitrous oxide and methane fluxes from organic soils under agriculture. Eur. J. Soil Sci. 49, 327-335. doi: http://doi.org/10.1046/j.1365-2389.1998.00156.x.

Freeman, C., Lock, M.A., Reynolds, B., 1993. Fluxes of $\mathrm{CO}_{2}, \mathrm{CH}_{4}$, and $\mathrm{N}_{2} \mathrm{O}$ from a Welsh peatland following simulation of water table draw-down: Potential feedback to climatic change. Biogeochem. 19, 51-60. http://www.jstor.org/stable/1468507.

Hamouz, K., Dvořák, P., Čepl, J., Pivec, J. 2005. The effect of polypropylene fleece covering on the yield of early potatoes. Hortic. Sci. (Prague) 32, 56-59.

Hamouz, K., Lachman, J., Dvořák, P., Trnková, E., 2006. Influence of non-woven fleece on the yield formation of early potatoes. Plant Soil Environ. 52, 289-294.

Henault, C., Grossel, A., Mary, B., Roussel, M., Leonard, J., 2012. Nitrous oxide emission by agricultural soils: A review of spatial and temporal variability for mitigation. Pedosphere 22, 426-433. doi: https://doi.org/10.1016/S1002-0160(12)60029-0.

HDC, 2006. Initial report: The scope for bio-degradable crop covers in vegetable production. Report for the Horticultural Development Council, Project FV280, April 2006. Available at: 

m\%20report\%20April\%202006.pdf (accessed May 2018).

608

609

610

611

612

613

614

615

616

617

618

619

620

621

622

623

624

625

626

627

628

629

Henderson, S.L., Dandie, C.E., Patten, C.L., Zebarth, B.J., Burton, D.L., Trevors, J.T., Goyer, C., 2010. Changes in denitrifier abundance, denitrification gene mRNA levels, nitrous oxide emissions, and dentrification in anoxic soil microcosms amended with glucose and plant residues. Appl. Environ. Microbiol. 76, 2155-2164. doi: https://doi.org/10.1128/AEM.02993-09.

Hutchinson, J.N., 1980. The record of peat wastage in the East Anglian Fenlands at Holme Post, 1848-1978 A. D. J. Ecol. 68, 229-249. http://www.jstor.org/stable/2259253.

IPCC, 2000. Good practice guidance and uncertainty management in national greenhouse gas inventories. IPCC, Geneva, Switzerland. Available at: http://www.ipcc-nggip.iges.or.jp/public/gp/english/ (accessed March 2018).

IPS, 2008. Peatlands and Climate Change. International Peatland Society, Jyväskylä, Finland. Available at: http://www.peatsociety.org/sites/default/files/files/PeatlandsandClimateChangeBookIP S2008.pdf (accessed March 2018).

Jauhiainen, J., Page, S.E., Vasander, H., 2016. Greenhouse gas dynamics in degraded and restored tropical peatlands. Mires Peat 17, UNSP 06. doi: https://doi.org/10.19189/MaP.2016.OMB.229.

Kasimir-Klemedtsson, Á., Klemedtsson, L., Berglund, K., Martikainen, P., Silvola, J., Oenema, O., 1997. Greenhouse gas emissions from farmer organic soils: A review. Soil Use Manage. 13, 245-250. doi: https://doi.org/10.1111/j.1475-2743.1997.tb00595.x.

Kechavarzi, C., Dawson, Q., Leeds-Harrison, P.B., Szatyłowicz, J., Gnatowski, T., 2007. Water-table management in lowland UK peat soils and its potential impact on $\mathrm{CO}_{2}$ 
630

631

632

633

634

635

636

637

638

639

640

641

642

643

644

645

646

647

648

649

650

651

652

653

emission. Soil Use Manage. 23, 359-367. doi: https://doi.org/10.1111/j.14752743.2007.00125.x.

Kløve, B., Berglund, K., Berglund, O., Weldon, S., Maljanen, M., 2017. Future options for cultivated Nordic peat soils: Can land management and rewetting control greenhouse gas emissions? Environ. Sci. Policy 69, 85-93. doi: https://doi.org/10.1016/j.envsci.2016.12.017.

Kuzyakov, Y., Friedel, J.K., Stahr, K., 2000. Review of mechanisms and quantification of priming effects. Soil Biol. Biochem. 32, 1485-1498. doi: http://dx.doi.org/ 10.1016/S0038-0717(00)00084-5.

Kuzyakov, Y., 2010. Priming effects: Interactions between living and dead organic matter. Soil Biol. Biochem. 42, 1363-1371. doi: http://dx.doi.org/10.1016/j. soilbio.2010.04.003.

Le Mer, J., Roger, P., 2001. Production, oxidation, emission and consumption of methane by soils: A review. Eur. J. Soil Biol. 37, 25-50. doi: https://doi.org/10.1016/S1164-5563(01)01067-6.

Leifeld, J., Müller, M., Fuhrer, J., 2011. Peatland subsidence and carbon loss from drained temperate fens. Soil Use Manage. 27, 170-176. doi: https://doi.org/10.1111/j.1475-2743.2011.00327.x.

Li, C. 2007. Quantifying greenhouse gas emissions from soils: Scientific basis and modeling approach. Soil Sci. Plant Nutr. 53, 344-352. doi: https://doi.org/10.1111/j.1747-0765.2007.00133.x.

Li, C., Frolking, S., Frolking, T.A., 1992. A model of nitrous oxide evolution from soil driven by rainfall events: 1. Model structure and sensitivity. J. Geophys. Res. 97, 97599776. doi: https://doi.org/10.1029/92JD00509. 
654

655

656

657

658

659

660

661

662

663

664

665

666

667

668

669

670

671

672

673

674

675

676

677

Lloyd, C.R., 2006. Annual carbon balance of a managed wetland meadow in the Somerset Levels, UK. Agric. For. Meteorol. 138, 168-179. doi: https://doi.org/10.1016/j.agrformet.2006.04.005.

Loecke, T.D., Robertson, G.P., 2009. Soil resource heterogeneity in terms of litter aggregation promotes nitrous oxide fluxes and slows decomposition. Soil Biol. Biochem. 41, 228-235. doi: https://doi.org/10.1016/j.soilbio.2008.10.017.

Maljanen, M., Martikainen, P.J., Aaltonen, H., Silvola, J., 2002. Short-term variation in fluxes carbon dioxide, nitrous oxide and methane in cultivated and forested organic boreal soils. Soil Biol. Biochem. 34, 577-584. doi: https://doi.org/10.1016/S00380717(01)00213-9.

Marella, V.S.S.R., Roberts, P., Hill, P.W., Jones, D.L., 2017. Different ways in which $\mathrm{CO}_{2}$ can be released during the turnover of roots in soil. Biol. Fertil. Soils 53, 369-374. doi: https://doi.org/10.1007/s00374-017-1193-1.

Miranda, K.M., Espey, M.G., Wink, D.A., 2001. A rapid, simple spectrophotometric method for simultaneous detection of nitrate and nitrite. Nitric Oxide 5, 62-71. doi: https://doi.org/10.1006/niox.2000.0319.

Mitsch, W.J., Gosselink, J.G., 2000. Wetlands. Third Edition. John Wiley \& Sons, New York, USA.

Mulvaney, R.L., 1996. Nitrogen - inorganic forms. In: Methods of Soil Analysis, Part 3: Chemical Methods (D.L. Sparks Ed.), pp. 1123-1184. Soil Science Society of America Madison, WI, USA.

Murphy, J., Riley, J.P., 1962. A modified single solution method for the determination of phosphate in natural waters. Anal. Chim. Acta 27, 31-36. doi: https://doi.org/10.1016/S0003-2670(00)88444-5. 
Musarika, S., Atherton, C.E., Gomersall, T., Wells, M.J., Kaduk, J., Cumming, A.M.J., Page, S.E., Oechel, W.C., Zona, D., 2017. Effect of water table management and elevated $\mathrm{CO}_{2}$ on radish productivity and on $\mathrm{CH}_{4}$ and $\mathrm{CO}_{2}$ fluxes from peatlands converted to agriculture. Sci. Total Environ. 584, 665-672. doi: https://doi.org/10.1016/j.scitotenv.2017.01.094.

Natural England, 2010. England's peatlands: carbon storage and greenhouse gases. Natural England, Worcester, UK. Available at: http://publications.naturalengland.org.uk/publication/30021 (accessed March 2018).

Olle, M., Bender, I., 2010. The effect of non-woven fleece on the yield and production characteristics of vegetables. Agraarteadus XXX(1): 24-29. Available at: http://agrt.emu.ee/pdf/2010_1_olle.pdf (accessed May 2018).

Oomes, M.J.M., Kuikman, P.J., Jacobs, F.H.H., 1997. Nitrogen availability and uptake by grassland in mesocosms of two water levels and two water qualities. Plant Soil 192, 249-259. doi: https://doi.org/10.1023/A:1004261913464.

Reicosky, D.C., Gesch, R.W., Wagner, S.W., Gilbert, R.A., Wente, C.D., Morris, D.R., 2008. Tillage and wind effects on soil $\mathrm{CO}_{2}$ concentrations in muck soils. Soil Till. Res. 99, 221-231. doi: https://doi.org/10.1016/j.still.2008.02.006.

Richardson, S.J., Smith, J., 1977. Peat wastage in the East Anglian fens. J. Soil Sci. 28, 485489. doi: https://doi.org/10.1111/j.1365-2389.1977.tb02256.x.

Siwek, P., Libik, A., Zawicka, I., 2012. The effect of biodegradable nonwovens in butterhead lettuce cultivation for early harvest. Folia Hortic. 24, 161-166. doi: https://doi.org/10.2478/v10245-012-0020-2.

Siwek, P., Libik, A., Kalisz, A., Zawicka, I., 2013. The effect of biodegradable nonwoven direct covers on yield and quality of winter leek. Folia Hortic. 25, 61-65. doi: https://doi.org/10.2478/fhort-2013-0007. 
Smith, P., Martino, D., Cai, Z., Gwary, D., Janzen, H., Kumar, P., McCarl, B., Ogle, S., O'Mara, F., Rice, C., Scholes, B., Sirotenko, O., Howden, M., McAllister, T., Pan, G., Romanenkov, V., Schneider, U., Towprayoon, S., Wattenbach, M., Smith, J., 2008. Greenhouse gas mitigation in agriculture. Philos. Trans. R. Soc. B: Biol. Sci. 363, 789813. doi: https://doi.org/10.1098/rstb.2007.2184.

Stevens, P.A., Ormerod, S.J., Reynolds, B. 1997. Final report on the acid waters survey for Wales: Volume I. Institute of Terrestrial Ecology (Natural Environment Research Council) Project T07072R5 Final Report, July 1997.

Taft, H.E., Cross, P.A., Edwards-Jones, G., Moorhouse, E.R., Jones, D.L., 2017. Greenhouse gas emissions from intensively managed peat soils in an arable production system. Agric. Ecosyst. Environ. 237, 162-172. doi: https://doi.org/10.1016/j.agee.2016.11.015.

UK Parliament, 2008. Climate Change Act 2008. The Stationery Office Ltd., London, UK. Available at: https://www.legislation.gov.uk/ukpga/2008/27/pdfs/ukpga_20080027_en.pdf (accessed March 2018).

UK Met Office. 2014. UK Climate and weather statistics. Available at: http://www.metoffice.gov.uk/climate/uk/summaries/actualmonthly (accessed March 2014).

Velthof, G.L., Kuikman, P.J., Oenema, O., 2002. Nitrous oxide emission from soils amended with crop residues. Nutr. Cycl. Agroecosyst. 62, 249-261. doi: https://doi.org/10.1023/A:1021259107244.

Velthof, G.L., Oenema, O., 1997. Nitrous oxide fluxes from grassland in the Netherlands: II. Effects of soil type, nitrogen fertilizer application and grazing. Eur. J. Soil Sci. 46, 541549. doi: https://doi.org/10.1111/j.1365-2389.1995.tb01350.x. 
727 Weslien, P., Rütting, T., Kasimir-Klemedtsson, Á., Klemedtsson, L., 2012. Carrot cropping on organic soil is a hotspot for nitrous oxide emissions. Nutr. Cycl. Agroecosyst. 94,

729 249-253. doi: https://doi.org/10.1007/s10705-012-9538-5. 
Table 1. Major soil characteristics in the soil cores sampled at the start and end of the experimental period and for the control, water table at $-15 \mathrm{~cm}$ below soil surface $\left(\mathrm{WT}_{15}\right)$, water table at soil surface $\left(\mathrm{WT}_{0}\right)$, fleece cover $\left(\mathrm{C}_{\text {fleece }}\right)$, simulated till $\left(\mathrm{S}_{\text {till }}\right)$, surface applied crop residue $\left(\mathrm{CR}_{\text {surf }}\right)$, and incorporated crop residue $\left(\mathrm{CR}_{\text {incorp }}\right)$ treatments. Values are presented as mean \pm SEM. Significant differences between initial core values and post-experiment values for each treatment (within each soil layer) are marked with * for $p<0.05$, ** for $p<0.01$, *** for $p<0.001$, and ${ }^{\dagger}$ for non-parametric (Kolmogorov-Smirnov Z statistic, Bonferroni corrected).

\begin{tabular}{|c|c|c|c|c|c|c|c|c|c|}
\hline Treatment & $\begin{array}{l}\text { Depth } \\
\text { (cm) }\end{array}$ & $\begin{array}{l}\text { Soil moisture } \\
\text { (\% DW })\end{array}$ & $\begin{array}{l}\text { Bulk density } \\
\left(\mathrm{g} \mathrm{cm}^{-3}\right)\end{array}$ & $\begin{array}{c}\mathrm{pH} \\
\left(\mathrm{H}_{2} \mathrm{O}\right)^{\mathrm{a}}\end{array}$ & $\begin{array}{c}\text { EC } \\
\left(\mu \mathrm{S} \mathrm{cm}^{-1}\right)^{\mathrm{s}}\end{array}$ & $\begin{array}{c}\text { Available K } \\
\left(\mathrm{g} \mathrm{K} \mathrm{kg}^{-1}\right)\end{array}$ & $\begin{array}{l}\text { Available P } \\
\left(\mathrm{g} \mathrm{P} \mathrm{kg}^{-1}\right)\end{array}$ & $\begin{array}{l}\text { Available } \mathrm{NO}_{3} \\
\quad\left(\mathrm{~g} \mathrm{~N} \mathrm{~kg}^{-1}\right)\end{array}$ & $\begin{array}{c}\text { Available } \mathrm{NH}_{4}^{+} \\
\quad\left(\mathrm{g} \mathrm{N} \mathrm{kg}^{-1}\right)\end{array}$ \\
\hline \multirow[t]{3}{*}{ Initial } & $0-10$ & $152 \pm 1$ & $0.68 \pm 0.01$ & $6.2 \pm 0.08$ & $598 \pm 50$ & $0.96 \pm 0.21$ & $0.39 \pm 0.01$ & $0.15 \pm 0.016$ & $0.05 \pm 0.024$ \\
\hline & $10-20$ & $156 \pm 2$ & $0.76 \pm 0.02$ & $6.2 \pm 0.06$ & $552 \pm 49$ & $0.63 \pm 0.11$ & $0.38 \pm 0.01$ & $0.15 \pm 0.033$ & $0.04 \pm 0.008$ \\
\hline & $20-30$ & $163 \pm 5$ & $0.75 \pm 0.02$ & $6.3 \pm 0.06$ & $401 \pm 24$ & $0.56 \pm 0.11$ & $0.35 \pm 0.02$ & $0.13 \pm 0.033$ & $0.03 \pm 0.001$ \\
\hline \multicolumn{10}{|c|}{ Post-experiment } \\
\hline \multirow[t]{3}{*}{ Control } & $0-10$ & $164 \pm 1^{\dagger}$ & $0.73 \pm 0.01 *$ & $6.7 \pm 0.04^{\dagger}$ & $161 \pm 13$ & $0.54 \pm 0.08$ & $0.27 \pm 0.02^{\dagger}$ & $0.01 \pm 0.001^{\dagger}$ & $<0.01$ \\
\hline & $10-20$ & $168 \pm 2 * *$ & $0.77 \pm 0.01$ & $6.7 \pm 0.06 * * *$ & $166 \pm 8$ & $0.51 \pm 0.19$ & $0.27 \pm 0.01 * *$ & $0.03 \pm 0.004^{\dagger}$ & $<0.01$ \\
\hline & $20-30$ & $180 \pm 2$ & $0.75 \pm 0.01$ & $6.7 \pm 0.04 *$ & $220 \pm 9 * * *$ & $0.58 \pm 0.15$ & $0.21 \pm 0.04$ & $0.06 \pm 0.008$ & $<0.01$ \\
\hline \multirow[t]{3}{*}{$\mathrm{WT}_{15}$} & $0-10$ & $170 \pm 1^{\dagger}$ & $0.74 \pm 0.01 * *$ & $6.7 \pm 0.04^{\dagger}$ & $136 \pm 3$ & $0.63 \pm 0.08$ & $0.29 \pm 0.02^{\dagger}$ & $0.01 \pm 0.001^{\dagger}$ & $<0.01$ \\
\hline & $10-20$ & $171 \pm 2 * * *$ & $0.78 \pm 0.01$ & $6.7 \pm 0.03 * * *$ & $160 \pm 6$ & $0.50 \pm 0.13$ & $0.31 \pm 0.02$ & $0.02 \pm 0.001^{\dagger}$ & $<0.01$ \\
\hline & $20-30$ & $175 \pm 6$ & $0.75 \pm 0.01$ & $6.7 \pm 0.03^{*}$ & $223 \pm 11 * * *$ & $0.44 \pm 0.10$ & $0.26 \pm 0.04$ & $0.03 \pm 0.006$ & $<0.01$ \\
\hline \multirow[t]{3}{*}{$\mathrm{WT}_{0}$} & $0-10$ & $172 \pm 1^{\dagger}$ & $0.74 \pm 0.01 * *$ & $6.7 \pm 0.03^{\dagger}$ & $159 \pm 8$ & $0.61 \pm 0.16$ & $0.27 \pm 0.01^{\dagger}$ & $0.01 \pm 0.001^{\dagger}$ & $<0.01$ \\
\hline & $10-20$ & $169 \pm 3 * *$ & $0.78 \pm 0.02$ & $6.8 \pm 0.07 * * *$ & $176 \pm 17$ & $0.62 \pm 0.16$ & $0.27 \pm 0.01 * *$ & $0.02 \pm 0.001^{\dagger}$ & $<0.01$ \\
\hline & $20-30$ & $174 \pm 5$ & $0.77 \pm 0.01$ & $6.7 \pm 0.06^{* *}$ & $196 \pm 16^{* * *}$ & $0.49 \pm 0.17$ & $0.33 \pm 0.04$ & $0.02 \pm 0.003^{\dagger}$ & $<0.01$ \\
\hline \multirow[t]{3}{*}{$\mathrm{C}_{\text {fleece }}$} & $0-10$ & $161 \pm 2^{\dagger}$ & $0.73 \pm 0.01$ & $6.6 \pm 0.05^{\dagger}$ & $154 \pm 9$ & $0.42 \pm 0.07$ & $0.35 \pm 0.03$ & $0.01 \pm 0.001$ & $<0.01$ \\
\hline & $10-20$ & $166 \pm 3^{*}$ & $0.76 \pm 0.01$ & $6.4 \pm 0.05^{*}$ & $205 \pm 20^{\dagger}$ & $0.45 \pm 0.12$ & $0.31 \pm 0.01$ & $0.04 \pm 0.006$ & $<0.01$ \\
\hline & $20-30$ & $175 \pm 5$ & $0.76 \pm 0.01$ & $6.4 \pm 0.05$ & $321 \pm 10^{* *}$ & $0.42 \pm 0.11$ & $0.31 \pm 0.02$ & $0.10 \pm 0.003$ & $<0.01$ \\
\hline \multirow[t]{3}{*}{$S_{\text {till }}$} & $0-10$ & $158 \pm 2$ & $0.62 \pm 0.01 * * *$ & $6.7 \pm 0.08$ & $133 \pm 13^{\dagger}$ & $0.49 \pm 0.08$ & $0.31 \pm 0.01^{\dagger}$ & $0.01 \pm 0.001^{\dagger}$ & $<0.01$ \\
\hline & $10-20$ & $166 \pm 2$ & $0.65 \pm 0.02 * * *$ & $6.6 \pm 0.07 * * *$ & $140 \pm 7^{\dagger}$ & $0.55 \pm 0.09$ & $0.30 \pm 0.03$ & $0.02 \pm 0.002^{\dagger}$ & $<0.01$ \\
\hline & $20-30$ & $175 \pm 2$ & $0.69 \pm 0.02$ & $6.5 \pm 0.08$ & $184 \pm 13^{* * *}$ & $0.61 \pm 0.14$ & $0.33 \pm 0.02$ & $0.04 \pm 0.006$ & $<0.01$ \\
\hline \multirow[t]{3}{*}{$\mathrm{CR}_{\text {surf }}$} & $0-10$ & $164 \pm 2^{\dagger}$ & $0.76 \pm 0.02 * * *$ & $6.7 \pm 0.03^{\dagger}$ & $139 \pm 2^{\dagger}$ & $0.59 \pm 0.03$ & $0.30 \pm 0.02$ & $0.01 \pm 0.001^{\dagger}$ & $<0.01$ \\
\hline & $10-20$ & $164 \pm 1$ & $0.76 \pm 0.01$ & $6.7 \pm 0.04 * * *$ & $149 \pm 6^{\dagger}$ & $0.49 \pm 0.10$ & $0.32 \pm 0.01$ & $0.02 \pm 0.001^{\dagger}$ & $<0.01$ \\
\hline & $20-30$ & $165 \pm 5$ & $0.76 \pm 0.01$ & $6.5 \pm 0.08$ & $178 \pm 4 * * *$ & $0.42 \pm 0.13$ & $0.29 \pm 0.04$ & $0.03 \pm 0.003$ & $<0.01$ \\
\hline \multirow[t]{3}{*}{$\mathrm{CR}_{\text {incorp }}$} & $0-10$ & $160 \pm 2$ & $0.59 \pm 0.01 * * *$ & $6.6 \pm 0.12$ & $142 \pm 12$ & $0.48 \pm 0.11$ & $0.30 \pm 0.02$ & $0.01 \pm 0.002$ & $<0.01$ \\
\hline & $10-20$ & $170 \pm 2 * * *$ & $0.65 \pm 0.01 * * *$ & $6.7 \pm 0.08 * * *$ & $159 \pm 3$ & $0.62 \pm 0.16$ & $0.35 \pm 0.02$ & $0.02 \pm 0.001$ & $<0.01$ \\
\hline & $20-30$ & $178 \pm 2$ & $0.71 \pm 0.01$ & $6.6 \pm 0.13$ & $184 \pm 10^{* * *}$ & $0.49 \pm 0.17$ & $0.34 \pm 0.03$ & $0.04 \pm 0.008$ & $<0.01$ \\
\hline
\end{tabular}

${ }^{\mathrm{a}} 1: 2.5(\mathrm{w} / \mathrm{v})$ field moist soil:distilled $\mathrm{H}_{2} \mathrm{O}$. 
Table 2. Summary of the control, water table, fleece, cultivation, and residue treatment characteristics used in the experiment.

\begin{tabular}{|c|c|c|c|c|}
\hline Treatment and code & $\begin{array}{l}\text { Water table depth } \\
(\mathrm{cm})\end{array}$ & $\begin{array}{l}\text { Lettuce biomass } \\
\left(\mathrm{g} \mathrm{FW} \mathrm{cm}^{-2} / \mathrm{t} \mathrm{FW} \mathrm{ha}^{-1}\right)^{\mathrm{a}}\end{array}$ & $\begin{array}{l}\text { Cultivation } \\
(\mathrm{cm})\end{array}$ & Soil cover \\
\hline Control & $>30 \mathrm{~cm}$ (free-draining) & None & None & None \\
\hline Low water table $\left(\mathrm{WT}_{15}\right)$ & $15 \mathrm{~cm}$ below soil surface & None & None & None \\
\hline High water table $\left(\mathrm{WT}_{0}\right)$ & $0 \mathrm{~cm}$ (at soil surface) & None & None & None \\
\hline Fleece $\left(\mathrm{C}_{\text {fleece }}\right)$ & $>30 \mathrm{~cm}$ (free-draining) & None & None & Fleece \\
\hline Soil tillage $\left(S_{\text {till }}\right)$ & $>30 \mathrm{~cm}$ (free-draining) & None & To $30 \mathrm{~cm}$ depth & None \\
\hline Crop residue, surface applied $\left(\mathrm{CR}_{\text {surf }}\right)$ & $>30 \mathrm{~cm}$ (free-draining) & $35.5 \mathrm{~g} \mathrm{~cm}^{-2} / 29.7 \mathrm{tha}^{-1}$ & None & Crop residue \\
\hline Crop residue, incorporated $\left(\mathrm{CR}_{\text {incorp }}\right)$ & $>30 \mathrm{~cm}$ (free-draining) & $35.5 \mathrm{~g} \mathrm{~cm}^{-2} / 29.7 \mathrm{t} \mathrm{ha}^{-1}$ & To $30 \mathrm{~cm}$ depth & None \\
\hline
\end{tabular}

Crop residue, incorporated $\left(\mathrm{CR}_{\text {incorp }}\right)$

${ }^{\mathrm{a}} \mathrm{FW}$, fresh weight.

Table 3. Cumulative fluxes of $\mathrm{CO}_{2}, \mathrm{~N}_{2} \mathrm{O}$ and $\mathrm{CH}_{4}$, and total cumulative $\mathrm{GHG}$ emissions $\left(G W P_{100}\right)$ in t $\mathrm{CO}_{2}$-e ha ${ }^{-1}$ period ${ }^{-1}$ ( $\pm \mathrm{SEM}$ ), for control, water table at -15 cm below soil surface $\left(\mathrm{WT}_{15}\right)$, water table at soil surface $\left(\mathrm{WT}_{0}\right)$, fleece cover $\left(\mathrm{C}_{\text {flecec }}\right)$, cultivated $\left(\mathrm{S}_{\text {till }}\right)$, surface applied crop residue $\left(\mathrm{CR}_{\text {surf }}\right)$, and incorporated crop residue $\left(\mathrm{CR}_{\text {incorp }}\right)$ treatments. For the water table treatments, totals are reported separately for the wetted (Phase I; months 0-3), drained (Phase II; months 4-6), and whole measurement period (Phase I + II; 0-6 months). Values are presented as mean \pm SEM. Significant differences among values for each treatment (within each column) at the $p<0.05$ level are marked with different letters, with separate comparisons made between (1) Control, $\mathrm{WT}_{15}$ and $\mathrm{WT}_{0}$ (denoted a-c), (2) Control and $\mathrm{C}_{\text {fleece }}$ (denoted d-e), (3) Control and $\mathrm{S}_{\text {till }}$ (ns), (4) Control and $\mathrm{CR}_{\text {surf }}$ (denoted f-g), (5) Control and $\mathrm{CR}_{\text {incorp }}$ (ns), and $\mathrm{CR}_{\text {surf }}$ and $\mathrm{CR}_{\text {incorp }}$ (denoted h-i).

\begin{tabular}{|c|c|c|c|c|c|c|c|c|c|c|c|c|}
\hline \multirow[t]{2}{*}{ Treatment } & \multicolumn{4}{|c|}{$\begin{array}{c}\text { Phase I } \\
\mathrm{t} \mathrm{CO}_{2}-\mathrm{e} \mathrm{ha}^{-1} 80 \mathrm{~d}^{-1}\end{array}$} & \multicolumn{4}{|c|}{$\begin{array}{c}\text { Phase II } \\
\mathrm{t} \mathrm{CO}_{2} \text {-e ha }{ }^{-1} 69 \mathrm{~d}^{-1}\end{array}$} & \multicolumn{4}{|c|}{$\begin{array}{c}\text { Phase I + II } \\
\mathrm{t} \mathrm{CO}_{2}-\mathrm{e} \mathrm{ha}^{-1} 153 \mathrm{~d}^{-1}\end{array}$} \\
\hline & $\mathrm{CO}_{2}$ & $\mathrm{~N}_{2} \mathrm{O}$ & $\mathrm{CH}_{4}$ & $G W P_{100}$ & $\mathrm{CO}_{2}$ & $\mathrm{~N}_{2} \mathrm{O}$ & $\mathrm{CH}_{4}$ & $G W P_{100}$ & $\mathrm{CO}_{2}$ & $\mathrm{~N}_{2} \mathrm{O}$ & $\mathrm{CH}_{4}$ & $G W P_{100}$ \\
\hline Control & $5.87 \pm 0.06 \mathrm{a}, \mathrm{d}, \mathrm{f}$ & $0.55 \pm 0.10 \mathrm{a}, \mathrm{f}$ & $0.00 \pm 0.01$ & $6.43 \pm 0.11 \mathrm{a}, \mathrm{d}, \mathrm{f}$ & $4.09 \pm 0.29 \mathrm{a}$ & $0.71 \pm 0.25$ & $0.01 \pm 0.01$ & $4.81 \pm 0.31$ & $10.29 \pm 0.35 \mathrm{a}$ & $1.36 \pm 0.37 \mathrm{a}$ & $0.01 \pm 0.01$ & $11.66 \pm 0.42 \mathrm{a}$ \\
\hline $\mathrm{WT}_{15}$ & $5.72 \pm 0.22 \mathrm{ab}$ & $7.70 \pm 0.92 \mathrm{~b}$ & $-0.00 \pm 0.01$ & $13.41 \pm 0.90 \mathrm{~b}$ & $4.58 \pm 0.11 \mathrm{ab}$ & $0.74 \pm 0.12$ & $0.00 \pm 0.02$ & $5.32 \pm 0.20$ & $10.61 \pm 0.30 \mathrm{a}$ & $8.82 \pm 1.11 \mathrm{~b}$ & $0.00 \pm 0.02$ & $19.42 \pm 1.14 \mathrm{~b}$ \\
\hline $\mathrm{WT}_{0}$ & $0.85 \pm 0.12 b$ & $1.16 \pm 0.37 \mathrm{a}$ & $-0.00 \pm 0.01$ & $2.01 \pm 0.45 c$ & $5.30 \pm 0.23 b$ & $0.44 \pm 0.21$ & $0.01 \pm 0.01$ & $5.75 \pm 0.37$ & $6.47 \pm 0.20 \mathrm{~b}$ & $1.71 \pm 0.43 \mathrm{a}$ & $0.01 \pm 0.01$ & $8.19 \pm 0.58 \mathrm{c}$ \\
\hline $\mathrm{S}_{\text {till }}$ & $5.63 \pm 0.22$ & $0.50 \pm 0.10$ & $0.01 \pm 0.00$ & $6.14 \pm 0.27$ & & & & & & & & \\
\hline $\mathrm{C}_{\text {flece }}$ & $7.83 \pm 0.58 \mathrm{e}$ & $1.20 \pm 0.25$ & $0.03 \pm 0.04$ & $9.07 \pm 0.58 \mathrm{e}$ & & & & & & & & \\
\hline $\mathrm{CR}_{\text {surf }}$ & $7.07 \pm 0.26 \mathrm{~g}, \mathrm{~h}$ & $1.42 \pm 0.29 \mathrm{~g}$ & $-0.05 \pm 0.02$ & $8.44 \pm 0.30 \mathrm{~g}$ & & & & & & & & \\
\hline $\mathrm{CR}_{\text {incorp }}$ & $5.99 \pm 0.18 \mathrm{i}$ & $0.78 \pm 0.22$ & $0.01 \pm 0.01$ & $6.79 \pm 0.34$ & & & & & & & & \\
\hline
\end{tabular}


Table 4. Significant linear correlations between measured environmental variables and emissions of $\mathrm{CO}_{2}, \mathrm{~N}_{2} \mathrm{O}$ and $\mathrm{CH}_{4}$ for control, water table at -15 cm below soil surface $\left(\mathrm{WT}_{15}\right)$, water table at soil surface $\left(\mathrm{WT}_{0}\right)$, fleece cover $\left(\mathrm{C}_{\text {fleece }}\right)$, cultivated $\left(\mathrm{S}_{\text {till }}\right)$, surface applied crop residue $\left(\mathrm{CR}_{\text {surf }}\right)$, and incorporated crop residue $\left(\mathrm{CR}_{\text {incorp }}\right)$ treatments. The values are reported separately for comparison against the water table treatments for the wetted (Phase I; months 0-3), drained (Phase II; months 4-6), and whole measurement period (Phase I + II; 0-6 months). Values are presented as Kendall's tau statistic $(\tau)$, with significance levels presented as $*(p<0.05)$, $* *(p<0.01)$, or $* * *(p<0.001)$.

\begin{tabular}{|c|c|c|c|c|c|c|c|c|c|c|c|c|c|}
\hline \multicolumn{2}{|c|}{ Treatment } & \multirow{2}{*}{\multicolumn{4}{|c|}{$\begin{array}{c}\text { Soil redox potential, } E_{\mathrm{h}}(\mathrm{mV}) \\
\text { Soil depth }(\mathrm{cm})\end{array}$}} & \multicolumn{3}{|c|}{ Temperature } & \multicolumn{2}{|c|}{ Rainfall } & \multicolumn{3}{|c|}{ Nitrogen availability } \\
\hline & & & & & & $\begin{array}{l}\text { Soil temp. }{ }^{\text {a }} \\
\left({ }^{\circ} \mathrm{C}\right)\end{array}$ & $\begin{array}{c}\text { Mean air temp. }{ }^{\mathrm{b}} \\
\left({ }^{\circ} \mathrm{C}\right)\end{array}$ & $\begin{array}{l}\text { Air temp. }{ }^{\mathrm{c}} \\
\left({ }^{\circ} \mathrm{C}\right)\end{array}$ & $\begin{array}{l}\text { Daily rain }{ }^{\mathrm{d}} \\
\text { (mm) }\end{array}$ & $\begin{array}{c}5 \mathrm{~d} \text { rain }^{\mathrm{e}} \\
(\mathrm{mm})\end{array}$ & $\begin{array}{l}\mathrm{NO}_{3}-\mathrm{N} \\
\left(\mathrm{mg} \mathrm{l}^{-1}\right)\end{array}$ & $\begin{array}{l}\mathrm{NH}_{4}-\mathrm{N} \\
\left(\mathrm{mg} \mathrm{l}^{-1}\right)\end{array}$ & $\begin{array}{c}\mathrm{N} \\
\left(\mathrm{mg}^{-1}\right)\end{array}$ \\
\hline \multirow{12}{*}{$\mathrm{CO}_{2}$} & Control, wetted & & & & & $0.539^{* * * *}$ & $0.617 * * *$ & $0.322 * * *$ & & $-0.174 *$ & & $0.254 * *$ & \\
\hline & $\begin{array}{l}\mathrm{WT}_{15} \text {, wetted } \\
\mathrm{WT}_{0} \text {, wetted }\end{array}$ & & & & & 0.559 *** & $0.538 * * *$ & $0.420^{* * *}$ & $\begin{array}{l}-0.238^{* * *} \\
-0.169 *\end{array}$ & $-0.360 * * *$ & $-0.152 *$ & $0.254 * *$ & $-0.199 *$ \\
\hline & Control, drained & & & $0.176^{*}$ & & $0.345 * * *$ & $0.384 * * *$ & $0.231 * *$ & 0.10 & $-0.219 * *$ & $0.182 *$ & $-0.187 *$ & \\
\hline & $\mathrm{WT}_{15}$, drained & & & $0.179 *$ & & $0.443 * * *$ & $0.442 * * *$ & $0.357 * * *$ & $-0.279 * * *$ & $-0.460 * * *$ & $0.445^{* * * *}$ & & \\
\hline & $\mathrm{WT}_{0}$, drained & & & & $-0.174 *$ & $0.474 * * *$ & $0.481 * * *$ & $0.395 * * *$ & $-0.289 * * * *$ & $-0.404 * * *$ & & & \\
\hline & Control, whole period & & & & & $0.381 * * *$ & $0.528 * * *$ & $0.279 * * *$ & & $-0.212 * * *$ & & & \\
\hline & $\mathrm{WT}_{15}$, whole period & & & & & $0.353 * * *$ & $0.523 * * *$ & $0.359 * * *$ & $-0.236 * * *$ & $-0.407 * * *$ & $-0.111 *$ & $0.135^{*}$ & \\
\hline & $\mathrm{WT}_{0}$, whole period & & & & & & $0.162 * *$ & & $-0.236^{* * * *}$ & $-0.130 * * *$ & $-0.298^{* * * *}$ & & $-0.191 * *$ \\
\hline & $\mathrm{C}_{\text {flece }}$ & & & & & $0.539 * * *$ & $0.595 * * *$ & $0.365 * * *$ & & $-0.153 *$ & & & \\
\hline & $\mathrm{S}_{\text {titll }}$ & & & & & $0.341 * * *$ & $0.392 * * *$ & $0.365^{* * * *}$ & & & $0.243 * *$ & $0.255^{* *}$ & \\
\hline & $\mathrm{CR}_{\text {surf }}$ & & & & & & $0.230^{* * *}$ & & $0.180 *$ & & & & $0.216 * *$ \\
\hline & $\mathrm{CR}_{\text {incorp }}$ & & & & & & $0.166^{*}$ & 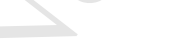 & $-0.112 *$ & & $0.219 *$ & & \\
\hline \multirow[t]{13}{*}{$\mathrm{N}_{2} \mathrm{O}$} & Control, wetted & & & & & & & & $-0.212^{* * *}$ & & $0.185^{*}$ & & \\
\hline & $\mathrm{WT}_{15}$, wetted & & & & & $0.180^{*}$ & & & $-0.579 * * *$ & $-0.260 * * *$ & & & \\
\hline & $\mathrm{WT}_{0}$, wetted & & & & & & & & $-0.357 * * *$ & & & & $0.207 *$ \\
\hline & Control, drained & & & & & & & & & & & & \\
\hline & $\mathrm{WT}_{15}$, drained & & & & $-0.174 *$ & $0.283 * * *$ & $0.258 * *$ & $0.345 * * *$ & $-0.271^{* *}$ & & $0.358^{* * *}$ & & $0.254 * *$ \\
\hline & $\mathrm{WT}_{0}$, drained & & & & $-0.254 *$ & $0.285^{* *}$ & $0.160 *$ & $0.302 * *$ & $-0.216^{*}$ & & & & \\
\hline & Control, whole period & & & & & & & & $-0.136 *$ & & & & \\
\hline & $\mathrm{WT}_{15}$, whole period & & & & & $0.313 * * *$ & & $0.204 * * *$ & $-0.440 * * *$ & $-0.199 * * *$ & $0.347 * * *$ & & $0.241^{* * *}$ \\
\hline & $\mathrm{WT}_{0}$, whole period & & & & & $0.153 * *$ & & $0.168 * *$ & $-0.291 * * *$ & & & & \\
\hline & $\mathrm{C}_{\text {flece }}$ & & & & & $0.147 *$ & & & $-0.237 * *$ & & & & \\
\hline & $\mathrm{S}_{\text {till }}$ & & & & & & & & $-0.240^{* *}$ & & & & \\
\hline & $\mathrm{CR}_{\text {surf }}$ & & & & & & $-0.185 *$ & $-0.171^{*}$ & $-0.186^{*}$ & & & $-0.292 * *$ & \\
\hline & $\mathrm{CR}_{\text {incorp }}$ & & & & & & $-0.171 *$ & & $-0.407 * * *$ & & & & \\
\hline \multirow[t]{11}{*}{$\mathrm{CH}_{4}$} & Control, wetted & & & & & & & & & & & & \\
\hline & $\mathrm{WT}_{15}$, wetted & & & & & & & & & & & & \\
\hline & $\mathrm{WT}_{0}$, wetted & & & & & & & & & & & & \\
\hline & Control, drained & & & & & $-0.170^{*}$ & $-0.164 *$ & $-0.179 *$ & & & & & \\
\hline & $\mathrm{WT}_{15}$, drained & & & & & & & & & & & & \\
\hline & $\mathrm{WT}_{0}$, drained & & & & & & & & & & & & \\
\hline & $\begin{array}{l}\text { Control, whole period } \\
\mathrm{W}_{15} \text {, whole period }\end{array}$ & & & & & & & & & & & & \\
\hline & $\mathrm{WT}_{0}$, whole period & & & & & & & & & & & & \\
\hline & $\mathrm{C}_{\text {fleece }}$ & & & & & & & & & & $0.179 *$ & $-0.239 * *$ & \\
\hline & $\mathrm{S}_{\text {till }}$ & & & & & & & & & & & & \\
\hline & $\begin{array}{l}\mathrm{CR}_{\text {surf }} \\
\mathrm{CR}_{\text {incorp }}\end{array}$ & & & & & $-0.461 *$ & & $-0.199 * *$ & & & & & \\
\hline
\end{tabular}

${ }^{\mathrm{a}}$ Soil temp., soil temperature at the time of GHG measurement; ${ }^{\mathrm{b}}$ Mean air temp., mean daily air temperature on the day of the GHG measurement; ${ }^{\mathrm{c}}$ Air temp., temperature at the time the GHG measurement was made; ${ }^{\mathrm{d}}$ Daily rain, rainfall on the day of GHG measurement; ${ }^{\mathrm{e}} 5 \mathrm{~d}$ rain, cumulative rainfall in the $5 \mathrm{~d}$ preceding the GHG measurement. 

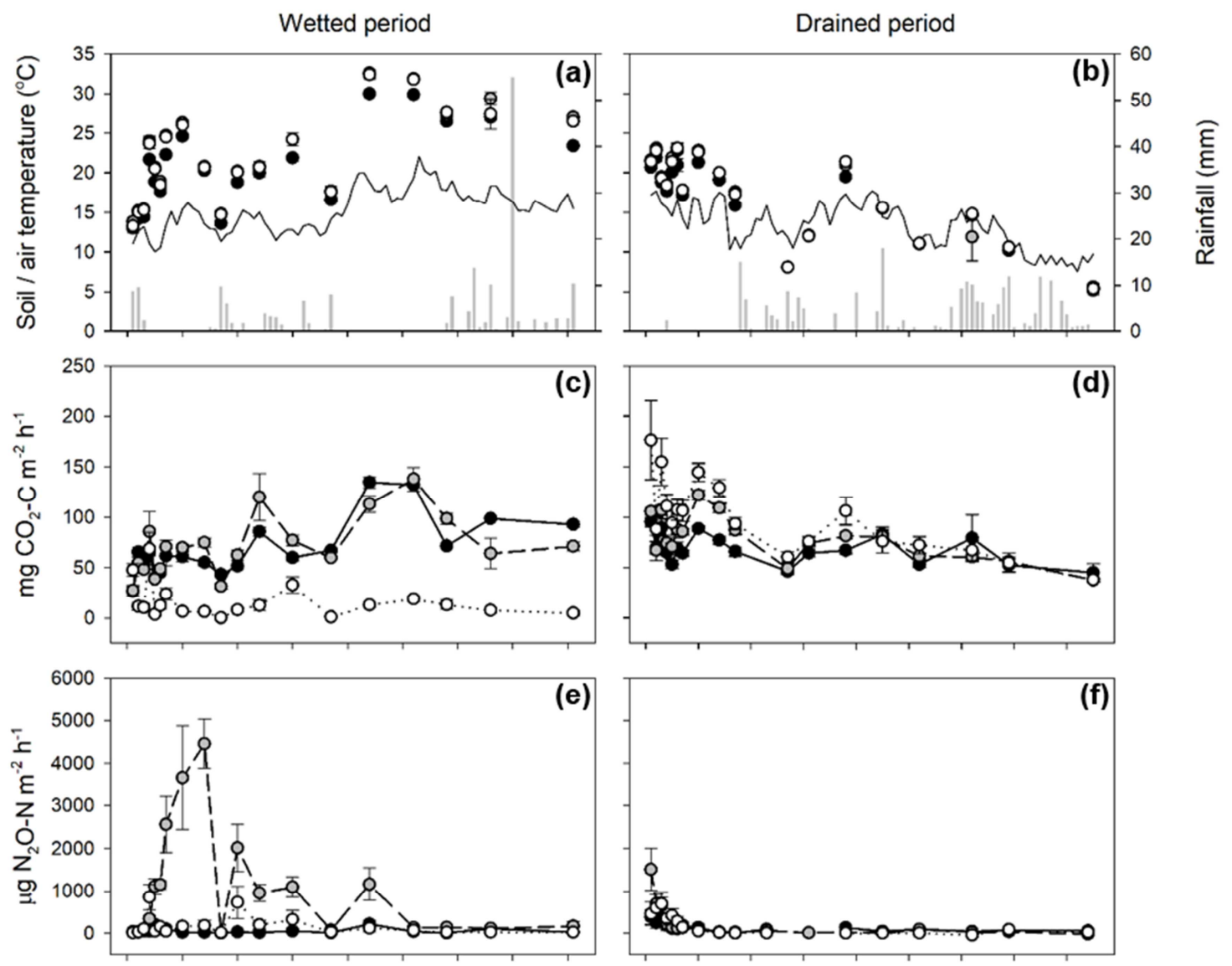

e)
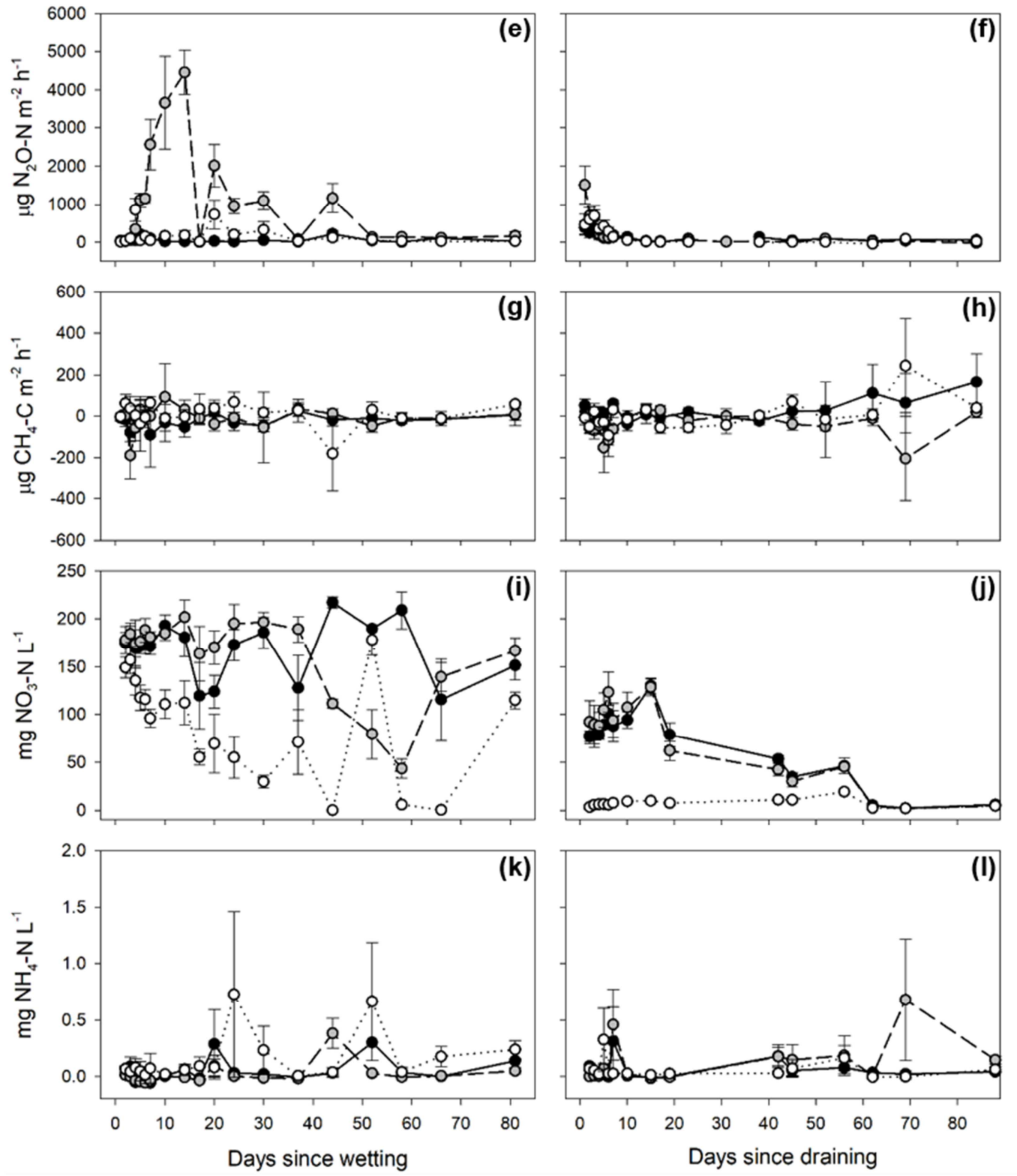
Fig. 1. Daily rainfall, air temperature and soil temperature (a-b); fluxes of $\mathrm{CO}_{2}(\mathrm{c}-\mathrm{d}), \mathrm{N}_{2} \mathrm{O}(\mathrm{e}-$ f), and $\mathrm{CH}_{4}$ (g-h); and soil water $\mathrm{NO}_{3}{ }^{-}(\mathrm{i}-\mathrm{j})$ and $\mathrm{NH}_{4}{ }^{+}$(k-1); $28^{\text {th }}$ May to $16^{\text {th }}$ Aug. (Phase I, wetted) and $21^{\text {st }}$ Aug. to $13^{\text {th }}$ Nov. 2013 (Phase II, drained). In panels (a)-(b), mean daily air temperature $\left({ }^{\circ} \mathrm{C}\right)$ is denoted by a solid black line, rainfall $(\mathrm{mm})$ by grey bars, and mean soil temperature by solid black circles (free-draining control), grey circles (water table at $15 \mathrm{~cm}$ below the soil surface, $\mathrm{WT}_{15}$ ), and white circles (water table at the soil surface, $\mathrm{WT}_{0}$ ). In panels (c)-(1), the control treatment is denoted by black circles with a solid line, $\mathrm{WT}_{15}$ by grey circles with a dashed line, and $\mathrm{WT}_{0}$ by white circles with a dotted line. Error bars represent \pm SEM. 

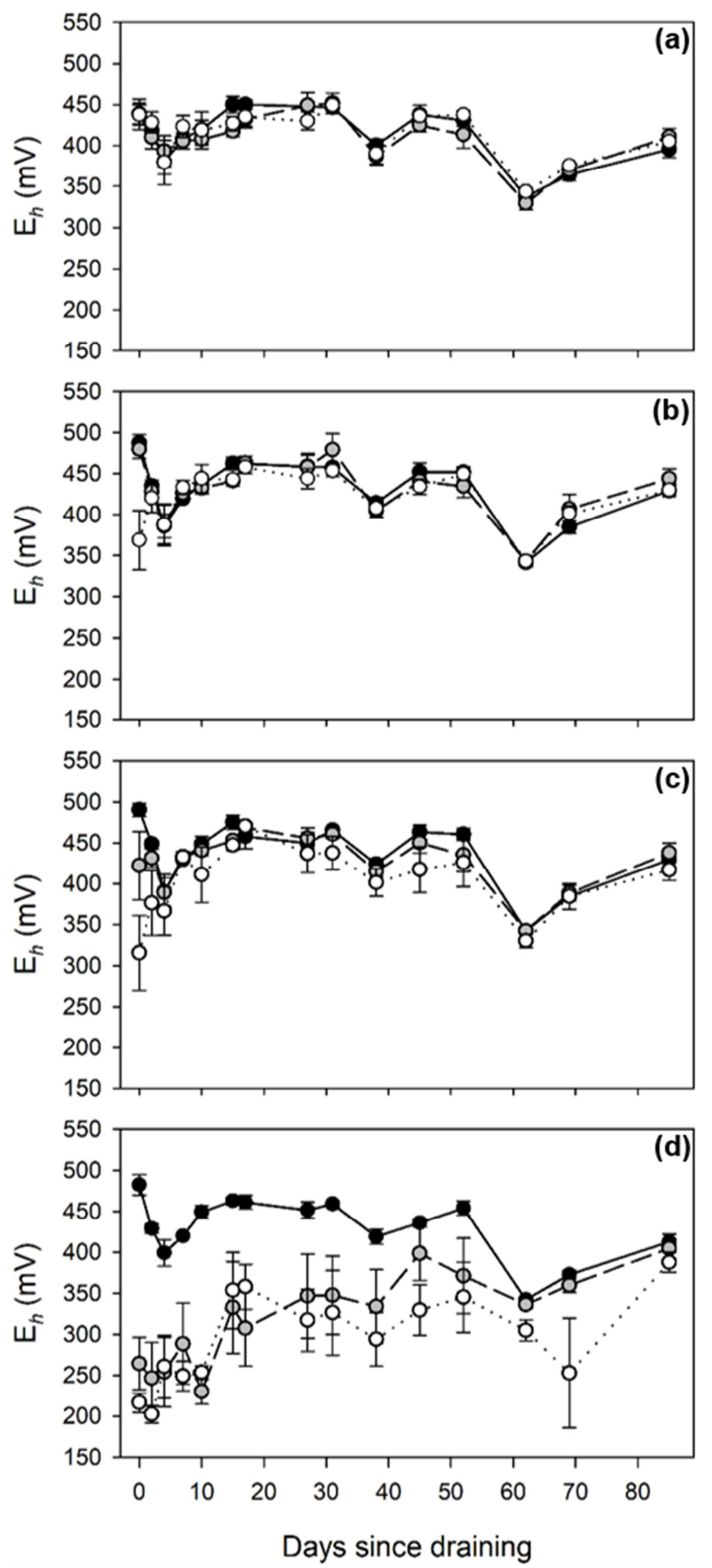

Fig. 2. Redox potentials $\left(E_{\mathrm{h}}\right)$ at soil depths of $0 \mathrm{~cm}(\mathrm{a}), 10 \mathrm{~cm}(\mathrm{~b}), 20 \mathrm{~cm}(\mathrm{c})$, and $30 \mathrm{~cm}(\mathrm{~d})$; $21^{\text {st }}$ Aug. to $13^{\text {th }}$ Nov. 2013 (Phase II, drained). The free-draining control treatment is denoted by black circles with a solid line, $\mathrm{WT}_{15}$ (water table at $15 \mathrm{~cm}$ below the soil surface) by grey circles with a dashed line, and $\mathrm{WT}_{0}$ (water table at the soil surface) by white circles with a dotted line. Error bars represent \pm SEM. 

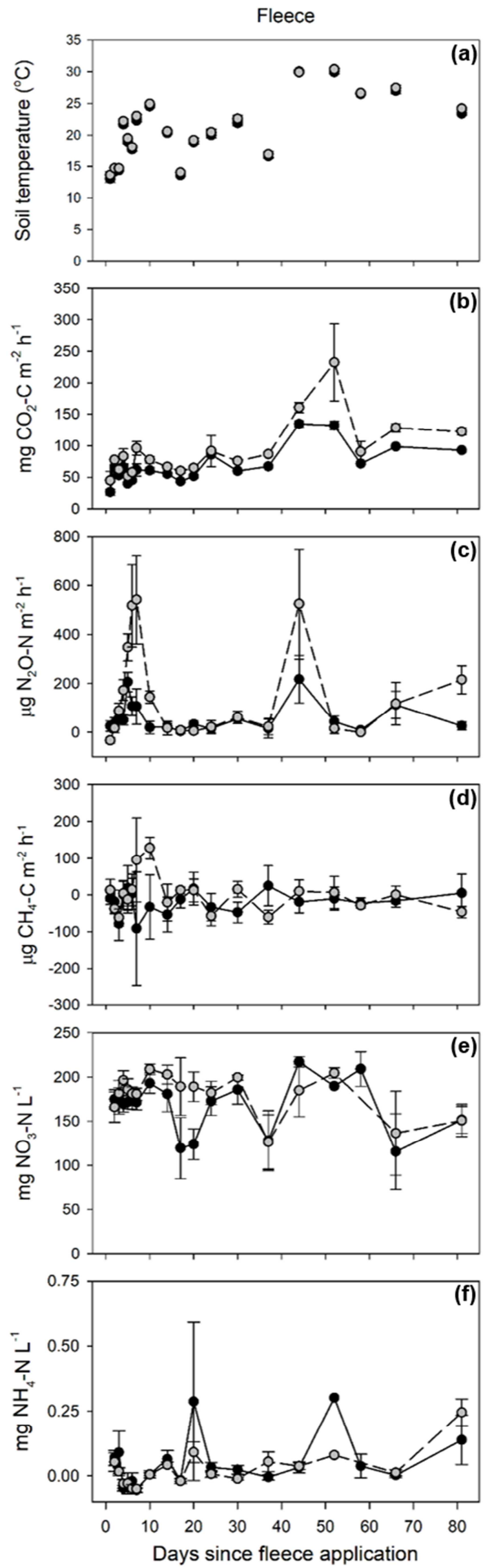
Fig. 3. Soil temperature (a); fluxes of $\mathrm{CO}_{2}$ (b), $\mathrm{N}_{2} \mathrm{O}$ (c), and $\mathrm{CH}_{4}(\mathrm{~d})$; and soil water $\mathrm{NO}_{3}{ }^{-}$(e) and $\mathrm{NH}_{4}{ }^{+}$(f); $28^{\text {th }}$ May to $16^{\text {th }}$ Aug. 2013. In panel (a), mean soil temperature is denoted by solid black circles (uncovered control), and grey circles (fleece applied, $\mathrm{C}_{\text {fleece }}$ ). In panels (b)(f), the control treatment is denoted by black circles with a solid line, and $\mathrm{C}_{\text {fleece }}$ by grey circles with a dashed line. Error bars represent \pm SEM. 

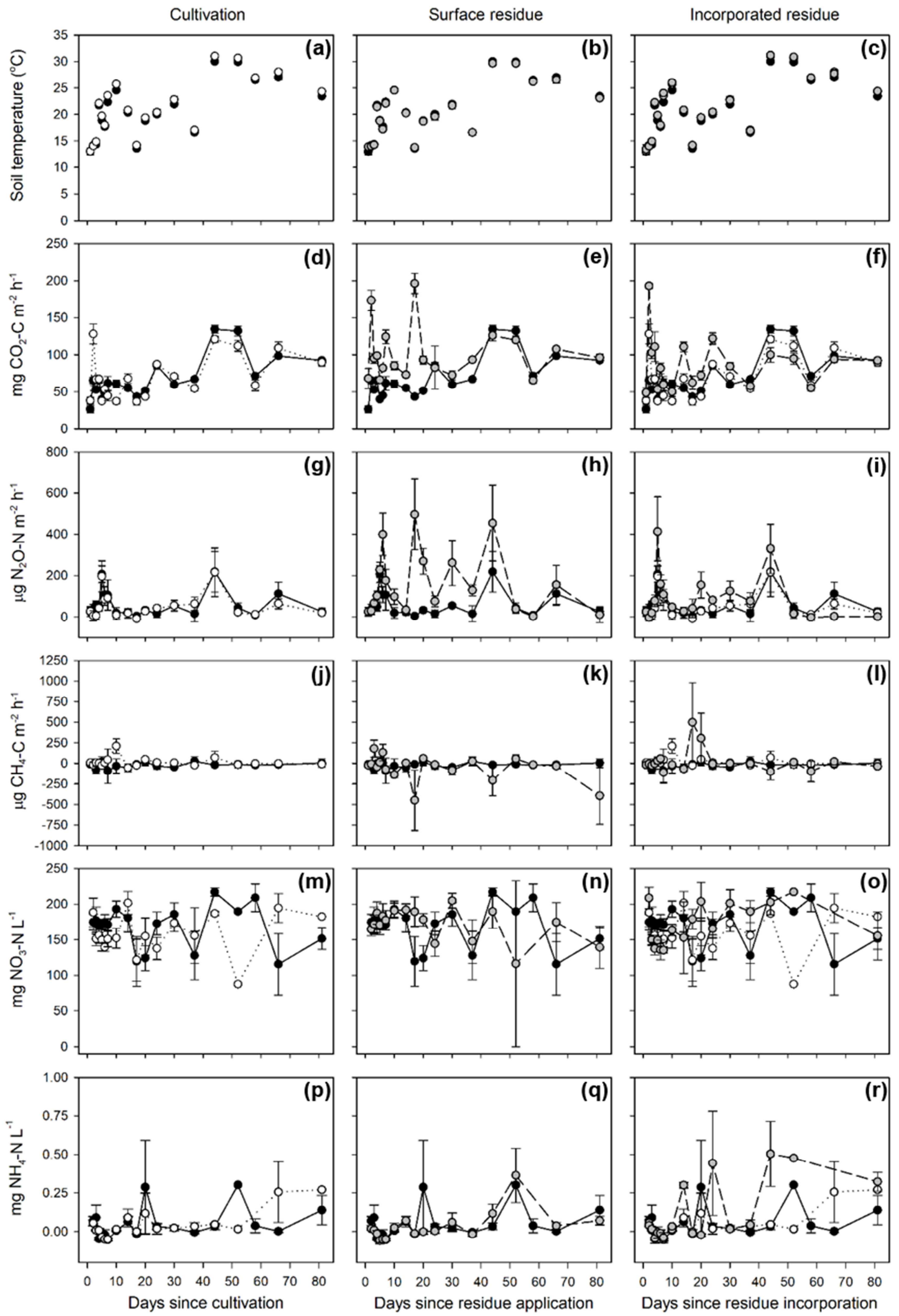
Fig. 4. Soil temperature (a-c); fluxes of $\mathrm{CO}_{2}$ (d-f), $\mathrm{N}_{2} \mathrm{O}$ (g-i), and $\mathrm{CH}_{4}(\mathrm{j}-1)$; and soil water $\mathrm{NO}_{3}{ }^{-}$(m-o) and $\mathrm{NH}_{4}{ }^{+}$(p-r); $28^{\text {th }}$ May to $16^{\text {th }}$ Aug. In panels (a)-(c), mean soil temperature is denoted by solid black circles (control without cultivation or residue), solid grey circles (surface applied residue, $\mathrm{CR}_{\text {surf }}$, or incorporated residue, $\mathrm{CR}_{\text {incorp }}$ ), and white circles (simulated tillage, $S_{\text {till }}$ ). In panels (d)-(r), the control treatment is denoted by black circles with a solid line, $\mathrm{CR}_{\text {surf }}$ and $\mathrm{CR}_{\text {incorp }}$ by grey circles with a dashed line, and $\mathrm{S}_{\text {till }}$ by white circles with a dotted line. Error bars represent \pm SEM. 


\section{RESEARCH HIGHLIGHTS}

- Greenhouse gas (GHG) emissions were measured in a horticultural fen peat soil.

- $\mathrm{CO}_{2}$ and $\mathrm{N}_{2} \mathrm{O}$ emissions were highly sensitive to water table depth changes.

- Tillage and horticultural fleece had no appreciable impact on GHG emissions.

- Crop residue addition did not appear to induce positive SOM priming.

- Alternative land uses are likely required to preserve these soils in the long-term. 